Federal Reserve Bank of Minneapolis

Research Department Staff Report 320

August 2003

\title{
An Evaluation of the Performance of Applied General Equilibrium Models of the Impact of NAFTA
}

\author{
Timothy J. Kehoe* \\ University of Minnesota \\ and Federal Reserve Bank of Minneapolis
}

\begin{abstract}
This paper evaluates the performances of three of the most prominent multisectoral static applied general equilibrium models used to predict the impact of the North American Free Trade Agreement. These models drastically underestimated the impact of NAFTA on North American trade. Furthermore, the models failed to capture much of the relative impacts on different sectors. Ex-post performance evaluations of applied GE models are essential if policymakers are to have confidence in the results produced by these models. Such evaluations also help make applied GE analysis a scientific discipline in which there are well-defined puzzles with clear successes and failures for competing theories. Analyzing sectoral trade data indicates the need for a new theoretical mechanism that generates large increases in trade in product categories with little or no previous trade. To capture changes in macroeconomic aggregates, the models need to be able to capture changes in productivity.
\end{abstract}

\footnotetext{
*I am grateful to the participants at the Frontiers in Applied General Equilibrium Modeling Conference at the Cowles Foundation, April 2002, especially Sherman Robinson, Jaime Serra-Puche, and T. N. Srinivasan, for valuable comments. I thank Kim Ruhl for excellent research assistance and the National Science Foundation for financial support. The data used in this paper are available at http://www.econ.umn.edu/ tkehoe/. The views expressed herein are those of the author and not necessarily those of the Federal Reserve Bank of Minneapolis or the Federal Reserve System.
} 


\section{INTRODUCTION}

Herbert Scarf's work on the computation of economic equilibrium has transformed the way economists think about putting general equilibrium (GE) theory to use. Previous economists — notably Leontief (1941), Johansen (1960), and Harberger (1962) — had matched simple GE models to data and used these models to answer important economic questions. Scarf's work $(1967,1973)$ on computation forged the link between applied GE analysis and the theory of general economic equilibrium developed by researchers like Arrow and Debreu (1954) and McKenzie (1959). Much of Scarf's influence in this field can be seen in the work of students such as Shoven and Whalley (1973). The work of researchers in the Scarf school of applied GE analysis is characterized by a focus on important economic issues, by a careful treatment of the data, and — most distinctly — by a rigorous grounding of the model in economic theory.

This paper stresses the need for a different sort of rigor in applied GE analysis. We need to constantly test our theories by matching the results from our models with the data.

Some tests will confirm our theories. Suppose, for example, that we are interested in building a model of the impact of China's joining the World Trade Organization (WTO). We could take a model with the same theoretical structure, calibrate it to the economies of North America in the early 1990s, and carry out numerical experiments in which we change policy parameters to simulate Mexico's joining the North American Free Trade Area (NAFTA — also the acronym for the North American Free Trade Agreement, which established this organization). If the model is capable of capturing the impact of this trade liberalization between a developing country and its richer neighbors, we would have some confidence in applying a model with the same theoretical structure to later trade liberalizations. There will always be some uncertainty about predictions, of course, because of uncertainty about choices of parameters or uncertainty about other shocks that might buffet the economy. Furthermore, we probably will want to modify some of this theoretical structure of the Mexico-NAFTA model to fit the institutional details of the China-WTO experience.

Even more importantly, in matching the results from our models with the data, some tests will establish puzzles that can only be resolved by modifications in the theory. If our proposed model of China's joining the WTO fails to capture the impact of previous trade liberalizations, 
we would want to change its theoretical structure before applying it. To the extent that applied GE analysis is a scientific discipline, failures of the theory can be even more important than confirmations for making progress.

In the early 1990s, the tool of choice for analyzing the impact of NAFTA on the economies of Canada, Mexico, and the United States was the multisectoral applied GE model. In fact, at a U.S. International Trade Commission conference held in February 1992 at the request of the U.S. Congress, to which all economists studying the economywide impact of NAFTA had been invited, 10 of the 12 studies presented used applied GE models. These studies were collected in United States International Trade Commission (1992); revised versions of most of the papers were later published in Francois and Shiells (1994). ${ }^{1}$

This paper uses economic data to systematically evaluate the performance of three of the most prominent applied GE models that had been constructed to predict the impact of NAFTA: the Brown-Deardorff-Stern model of all three North American economies (see Brown 1992, 1994 and Brown, Deardorff, and Stern 1992, 1995), the Cox-Harris model of Canada (see Cox 1994, 1995 and Cox and Harris 1992a, 1992b), and the Sobarzo model of Mexico (see Sobarzo 1992a, 1992b, 1994, 1995). Given the importance of the NAFTA policy debate, it is surprising that no one has carried out such a model evaluation exercise previously.

NAFTA presents an important policy experiment that allows economic researchers to test modeling strategies, particularly the specifications of imperfect competition and product differentiation that characterized most of the applied GE trade models used in the early 1990s. Indeed, much is to be learned from the model evaluation exercise: The models drastically underestimated the impact of NAFTA on North American trade, which has exploded over the past decade. Furthermore, the models failed to capture much of the relative impacts on different sectors.

After evaluating the performance of the three applied GE models, we speculate about the theoretical features more successful models would need to include. Analysis of sectoral trade data indicates the need for a new theoretical mechanism for generating trade in the models - a

\footnotetext{
${ }^{1}$ The two studies that did not use applied GE models were (1) a macroeconometric forecasting model linked with country-specific input-output models developed by the Interindustry Research Fund and summarized by Shiells and Shelburne (1992) and (2) an outline of the issues involved in modeling capital flows and productivity growth by Kehoe (1992) along with calculations of the relative magnitudes of these sorts of dynamic factors.
} 
mechanism in which large increases in trade can take place in product categories with little or no previous trade. To capture changes in macro aggregates, the models must be able to capture changes in productivity. Although foreign investment is crucial in determining relative prices and the allocation of production across traded and nontraded goods sectors, its impact on macro aggregates is felt mostly through its impact on productivity.

\section{APPLIED GE MODELS CAN DO A GOOD JOB: SPAIN 1985-1986}

To illustrate the sort of ex-post performance evaluation that is possible for an applied GE model, we evaluate the performance of a model constructed by a team at the Universitat Autònoma de Barcelona in 1985-1986. This model was used to analyze the impact on the Spanish economy of the reforms implemented in 1986 to accompany Spain's entry into (what was then) the European Community (EC). The results obtained in this analysis were issued as working papers or published in a variety of outlets (see Kehoe, Manresa, Noyola, Polo, Sancho, and Serra-Puche 1985, 1986a, 1986c; Kehoe, Manresa, Noyola, Polo, and Sancho 1988; and Kehoe, Manresa, Polo, and Sancho 1989).

Kehoe, Polo, and Sancho (1995) have compared the results generated by the model with the changes that actually occurred in Spain during the period 1985-1986. They find that the model performed well in capturing the changes that actually occurred. This is particularly true when they incorporate two major exogenous shocks that hit the Spanish economy in 1986: a decline in productivity in the agricultural sector, due mostly to weather conditions, and a sharp fall in the international price of petroleum. Like a few other applied GE researchers - notably Johansen (1960) and Dervis, de Melo, and Robinson (1982) — Kehoe, Polo, and Sancho (1995) investigate how well their model did in tracking the impact of policy changes and external shocks after these changes occurred. Like Adams, Dixon, McDonald, Meagher, and Parmenter (1994), they also compare the data with some model results that were pure predictions when they were made.

Spain's 1986 entry into the European Community was accompanied by two major government policy reforms. The first, and most significant, policy reform introduced a 
consumption value added tax to replace the previous indirect tax system. The second policy reform reduced trade barriers and investment barriers with other EC countries. In contrast with the fiscal policy reform, which took place immediately, the trade policy reform was scheduled to be phased in gradually over six years. The part of the trade reform that took place in 1986 mostly involved reductions in tariff rates. The various versions of the Spanish model incorporated the tax and tariff parameters that correspond to both these policy reforms into the model. It should be stressed, however, that the parameter changes involved in the tax reform were far larger than those involved in the trade reform. In this section, we confront the results generated by the model with the data that describe the changes that actually took place in the Spanish economy during the period 1985-86. It is changes over a one- or two-year time horizon that Kehoe, Polo, and Sancho (1995) argue that this type of model can capture. On one hand, this time horizon is long enough to allow enough gestation and depreciation of capital stocks in each sector to justify assuming mobility of capital, provided changes in capital utilization by sector are less than, say, 10 percent. On the other hand, this time horizon is short enough to justify ignoring secular trends and the intersectoral impact of changes in productivity and population growth rates. More modern applied GE models would specify a dynamic structure with explicit treatment of gestation, depreciation, productivity growth, and population growth.

In reporting both the simulation results and the actual data, we deflate by an appropriate price or output index. The weights used in the different indices are taken from the 1980 social accounting matrix constructed by Kehoe, Manresa, Noyola, Polo, Sancho, and Serra-Puche (1986b) and Kehoe, Manresa, Polo, and Sancho (1988) that provided the data set for the calibration of the model. The precise question that the numerical experiments answered, therefore, was,

Suppose that the tax and tariff changes adopted by the Spanish government in 1986 to accompany the integration into the European Community had been adopted in 1980. What would the impact have been?

Since the model was calibrated to a different year than the year in which the tax reform took place, the choice of weights is somewhat arbitrary. Fortunately, calculations not reported here indicate that the results are not sensitive to this choice. In retrospect, it would have been 
preferable to use weights that correspond to the base period for the numerical experiments, that is, to the year before the reform took place, in this case 1985. This would have allowed us to compare the results of this model with the results of other models calibrated to different data sets. Even better, the model could have been recalibrated to match aggregates in 1985, even if some micro parameters necessarily would still have depended on 1980 data for their calibration. Such a recalibration would allow us to take more seriously the comparison between changes in the data over the period 1985-1986 with the results of numerical experiments using the model.

Tables 1-4 present the actual changes that occurred in the Spanish economy over the period 1985-86 in terms of relative prices of consumer goods, composition of output, macroeconomic aggregates, and trade patterns. Comparing the first column in table 1 with the second column, we see that the model did poorly in predicting the changes that actually took place in two large sectors, food and transportation. The reasons for this are readily apparent to observers of the Spanish economy in 1986. In that year, food prices rose sharply because of a poor harvest, and energy prices fell sharply because of both an appreciation of the peseta against the dollar and a fall in the dollar price of petroleum. The third column of table 1 reports the results of a numerical experiment that takes these two exogenous shocks into account in the simplest possible ways: We reduce the ratio of output to inputs in the agricultural production sector by 7.7 percent. This number is the fall in the ratio of an index of output to an index of intermediate inputs in agriculture from 1985 to 1986 . We also reduce the foreign price of energy by 47.6 percent. This number is the fall in the price index of energy imports relative to an overall import price index from 1985 to 1986. (See Kehoe, Polo, and Sancho 1995 for details.) The fourth column of table 1 reports the results of a numerical experiment that takes into account both the changes in policy and the two exogenous shocks. Keep in mind that, while the second column reports predictions of the model, the third and forth columns report results of numerical experiments that used information that was only available after 1986.

In comparing the results of the model with the data, we report four statistics that measure the goodness of prediction.

The first two statistics implicitly compare the match between the model's prediction of change and the actual change with the match between the prediction of no change and the actual change. The first statistic is the weighted correlation coefficient, with weights that correspond to the relative sizes of sectors in the base period as explained above. The second statistic is a 
decomposition of the weighted variance of changes in the data that is meant to measure the fraction of this variance accounted for by the predictions of the model. Let

$$
\bar{x}=\sum_{i=1}^{n} \alpha_{i} x_{i}
$$

be the weighted mean of a vector of percentage changes,

$$
\operatorname{var}(x)=\sum_{i=1}^{n} \alpha_{i}^{2}\left(x_{i}-\bar{x}\right)^{2}
$$

be the weighted variance of this vector of changes, and

$$
\operatorname{cov}(x, y)=\sum_{i=1}^{n} \alpha_{i}^{2}\left(x_{i}-\bar{x}\right)\left(y_{i}-\bar{y}\right)
$$

be the covariance of two vectors of changes. The weighted correlation coefficient is

$$
\operatorname{corr}\left(x^{\text {data }}, x^{\text {model }}\right)=\frac{\operatorname{cov}\left(x^{\text {data }}, x^{\text {model }}\right)}{\left(\operatorname{var}\left(x^{\text {data }}\right) \operatorname{var}\left(x^{\text {model }}\right)\right)^{1 / 2}} .
$$

A high correlation coefficient rewards predictions that have the right signs and relative magnitudes. It does not take into account the absolute magnitudes of changes, however. The decomposition of the weighted variance of the changes in the data is

$$
\operatorname{vardec}\left(x^{\text {data }}, x^{\text {model }}\right)=\frac{\operatorname{var}\left(x^{\text {model }}\right)}{\operatorname{var}\left(x^{\text {model }}\right)+\operatorname{var}\left(x^{\text {data }}-x^{\text {model }}\right)} .
$$

Although this measure has the advantage of taking into account absolute magnitudes of changes, it only measures well the fraction of variance accounted for by the model if the changes in the model are highly correlated with those in the data. Since variance is not a linear function of vectors of changes, 


$$
\begin{aligned}
\operatorname{var}\left(x^{\text {data }}\right) & =\operatorname{var}\left(x^{\text {model }}\right)+\operatorname{var}\left(x^{\text {data }}-x^{\text {model }}\right)+2 \operatorname{cov}\left(x^{\text {data }}, x^{\text {data }}-x^{\text {model }}\right) \\
& \neq \operatorname{var}\left(x^{\text {model }}\right)+\operatorname{var}\left(x^{\text {data }}-x^{\text {model }}\right),
\end{aligned}
$$

any variance decomposition statistic has to do something with the covariance term. Our statistic distributes the covariance proportionally.

The second two statistics are derived from running a weighted least-squares regression of actual changes on predicted changes:

$$
x_{i}^{\text {data }}=a+b x_{i}^{\text {model }}+e_{i} .
$$

Specifically, we estimate the coefficients $a$ and $b$ by solving the least-squared problem

$$
\operatorname{minimize} \sum_{i=1}^{n} \alpha_{i}\left(a+b x_{i}^{\text {model }}-x_{i}^{\text {data }}\right)
$$

The deviation of the estimated coefficient $b$ from 1 indicates how well the model does in predicting signs and the absolute magnitude of the changes in the data. The deviation of the estimated coefficient $a$ from 0 indicates how well the model does in matching the average change in the data. (Notice that, if changes are relative to an index, where the weighted sum of the changes equals 0 , then $a=0$.) The deviation of the $R^{2}$ statistic of this regression from 1 indicates how well the model does in predicting the relative magnitudes of the changes in the data, but since $R^{2}=\operatorname{corr}\left(x^{\text {data }}, x^{\text {model }}\right)^{2}$ in this simple sort of regression, we do not report this statistic. To a large extent, the final two statistics are substitutes for the first two, at least if we are willing to report an $R^{2}$ statistic for the regression. As more of these sorts of ex-post performance analyses are carried out, conventions for comparing model results with data will have to be established. At this point, we report the two different sets of statistics to illustrate different possibilities.

Tables 1 and 2 show that the model did a good job capturing the changes in relative prices and production levels that occurred in 1986, at least after we take into account the agricultural productivity shock and the petroleum price shock. The performance of the model in 
capturing changes in major macroeconomic variables, reported in table 3, is, at first glance, spectacular. Much of the model's success in this direction, however, lies in the fact that the model predicted that the tax reform would result in a substantial increase in indirect taxes paid by consumers. It is worth pointing out that in 1985 this prediction of the model was controversial and was treated with considerable skepticism by a number of policymakers in the Spanish government. That the 1986 fiscal reform would be a substantial tax increase was the central

prediction in all versions of the model, including the earliest one (Kehoe, Manresa, Noyola, Polo, Sancho, and Serra-Puche 1985) and does not depend on the incorporation of the agricultural productivity shock and the petroleum price shock into the model. Furthermore, this prediction required the full sectoral specification of the model to compare the value added tax with the previous indirect tax system where intermediate transactions were taxed and in which there were many different tax rates.

The performance of the model in capturing changes in trade patterns, reported in table 4, is less impressive than that for the macroeconomic variables reported in table 3 . It is worth noting that the Spanish model was not intended to capture changes in trade patterns, and the theoretical structure of the trade side of the model was extremely simple. This should be kept in mind in the next section when we evaluate the performance of the models of NAFTA, in which the emphasis was on trade.

\section{MODELS OF NAFTA DID NOT DO A GOOD JOB}

The typical sort of model used to analyze the impact of the North American Free Trade Agreement was a static applied GE model with a large number of industries, some form of imperfect competition, and a finite number of firms in some industries. Kehoe and Kehoe (1995) explain the theoretical structures of three of the most important models and show how these structures drive the results of the models: the Brown-Deardorff-Stern model of all three North American economies (see Brown, Deardorff, and Stern 1995), the Cox-Harris model of Canada (see Cox 1995), and the Sobarzo model of Mexico (see Sobarzo 1995).

Like a number of other models of NAFTA, the Brown-Deardorff-Stern model and the Cox-Harris model were extensions to include Mexico of previous models constructed to analyze the Canada-U.S. Free Trade Agreement (see Brown and Stern 1989 and Cox and Harris 1985). This fact helps explain the importance of increasing returns and imperfect competition in the 
structure of the models. The "New Trade Theory" developed by such researchers as Krugman (1979) had adapted the industrial organization theory of monopolistic competition of Dixit and Stiglitz (1977) to account for the large volumes of trade observed between such economically similar countries as Canada and the United States. Models in which trade depends on differences across countries - as in the Heckscher-Ohlin form of differences in endowments and/or in the Ricardian form of differences in technologies — have trouble accounting for this trade. Furthermore, Harris (1984) had found that an applied GE model with some form of imperfect competition - in Harris's case a collusive pricing rule called Eastman-Stykolt pricing predicted far larger impacts of trade liberalization between Canada and the United States than did models in which trade depended on differences in endowments and/or technologies across countries.

Of course, analyzing the integration of Mexico into the Canada-U.S. FTA focused attention on issues that had not been as important in studies of just Canada and the United States. In particular, modelers were concerned with the impact of capital flows into Mexico. The static nature of most of the models of NAFTA limited their ability to predict the size and impact of such capital flows. Typically, capital flows were incorporated into experiments in which new capital owned by consumers in the rest of North America was placed in Mexico. Kehoe (1992) also stressed the importance of differences in the demographic structure of Mexico compared to those of its North American neighbors, the potential effects of NAFTA on productivity, especially in Mexico, and the potential for large capital flows to put Mexico in danger of a financial crisis. These sorts of dynamic factors were not incorporated into the models, however.

Tables 5-11 compare the predictions of the three models with changes in the data over the period 1988-1999. As with the comparisons of the Spanish model with the data in the previous section, the choice of years is somewhat arbitrary. The models had been calibrated to data from years different from 1993, the year before NAFTA went into force: The BrownDeardorff-Stern model was calibrated to a 1976 input-output matrix for Canada, a 1980 inputoutput matrix for Mexico, and a 1977 input-output matrix for the United States. Sectoral and macroeconomic aggregates were calibrated to 1989 data, but trade barriers were set equal to estimates from before the year in which the Canada-U.S. FTA had gone into force, 1989. The Cox-Harris model had been calibrated to a 1981 data set, but trade barriers were set equal to estimates from 1988. The Sobarzo model had been calibrated to a 1985 input-output matrix, but 
trade barriers were set equal to estimates from 1989. There are two considerations that determine the choice of the years 1988 and 1999 in our comparisons: First, the BrownDeardorff-Stern and Cox-Harris models included the changes in trade policies in the CanadaU.S. FTA in their numerical experiments, which makes 1988 the latest year possible for an initial year. Second, NAFTA included changes in trade barriers scheduled to be implemented over a 15-year period, that is, up until 2009, making the latest year available in the data the most attractive terminal year for our comparisons. The latest year for trade data in the World Bank's Trade and Production Database (Nicita and Olarreaga 2001), which serves as our data source, is 1999. (See the Appendix for details on the data that we use.)

Tables 5-8 compare changes in the data over the period 1988-1999 with the results of a numerical experiment of the Brown-Deardorff-Stern model that incorporated not just estimates of the changes in tariffs and nontariff trade barriers, but also a 10 percent increase in the capital stock in Mexico owned by consumers in Canada, the United Sates, and the rest of the world. The changes in both the data and the model results are calculated relative to the gross domestic product (GDP) of the country referred to in the change. For example, in the data in table 5, we calculate that Canadian exports increased by 52.9 percent relative to GDP as follows: Total Canadian exports increased from 116.418 billion U.S. dollars (USD) in 1988 to 237.337 billion USD in 1999. During the same period, Canadian GDP increased from 492.322 billion USD to 656.420 billion USD. We calculate

$$
1.529=\frac{0.362}{0.236}=\frac{237.337 / 656.420}{116.418 / 492.332} .
$$

In other words, Canadian exports increased from 23.6 percent of GDP in 1988 to 36.2 percent in 1999, and we say that the increase relative to GDP was 52.9 percent.

We strive to treat the model results the same way that we treat the data. Brown, Deardorff, and Stern (1995) reported that Canadian exports increased by 5.858 billion USD and that Canadian GDP increased by 0.7 percent in their numerical experiment. We calculate

$$
1.043=\frac{(116.418+5.858) / 116.418}{1.007} .
$$


In table 5, notice that the Brown-Deardorff-Stern model did a fairly good job of capturing the relative sizes of the increases in overall trade, predicting that the largest impact of NAFTA would be on Mexico, followed by Canada, and then the United States. The reported correlation coefficient, 0.74, is weighted using the sizes of trade in 1988. The model fails badly on magnitudes, however, and accounts for only a small fraction, 0.08 , of the variance in changes in trade shares observed in the data. Notice too how much larger than 0 is the coefficient $a$ and how much larger than 1 is the coefficient $b$ : To match what actually occurred, the best linear adjustment of the predictions for changes in trade patterns of the Brown-Deardorff-Stern model is to take these predictions, multiply them by a factor of 2.43 , and then add 23.20 percent to each.

Tables 6,7 , and 8 report comparisons between the changes in exports by sector for each of the three North American countries in the results of the Brown-Deardorff-Stern model with the changes that actually occurred in the data. Once again, all changes, both in the results of the numerical experiment and in the data, are calculated relative to GDP of the country. The correlation coefficients are weighted using the size of 1988 exports. Some of the correlations between predictions and changes in the data are fairly high. The correlation between the predictions and the data for Mexican exports to the United States in table 7, for example, is 0.71. This high correlation is driven largely by the prediction that exports of electrical machinery would increase more than the average increase in exports. Similarly, the weighted correlation between predictions and the data for U.S. exports to Mexico is fairly high, 0.50, because the model predicted that exports of electrical machinery would increase less than average (actually the model predicted a decrease) and that exports of transportation equipment would increase more than average. Electrical machinery and transportation equipment were the largest sectors both in Mexican exports to the United States and in U.S. exports to Mexico in 1988. The model failed badly in predicting relative magnitudes of sectoral changes for some other bilateral trade relationships, however. In the case of Canadian exports to Mexico, the model failed to predict the huge increases in exports of electrical machinery and of transportation equipment. In the case of U.S. exports to Canada, the model failed to predict the drop in exports of paper products. The variance decomposition statistics in tables 6,7 , and 8 come as no surprise given the results 
of the predictions of aggregates in table 5: The model missed completely on the magnitude of the changes in trade that occurred after NAFTA.

Tables 9 and 10 compare changes in the data over the period 1988-1999 with the results of a numerical experiment of the Cox-Harris model that incorporated the tariff changes in both NAFTA and the Canada-U.S. FTA. Like the Brown-Deardorff-Stern model, the Cox-Harris model does a good job predicting the relative sizes of the increases in overall trade, with Canadian trade with Mexico increasing much more than overall trade and Canadian trade with the United States increasing more than that with the rest of the world. The variance decomposition statistic is also fairly high at 0.52 . In this case, however, we can see a limitation of doing a decomposition of variance. What is important in our statistic are changes relative to the mean change. While these magnitudes are fairly close in the data and the model predictions, the mean change of the model predictions is much smaller than that of the changes in the data. An alternative statistic that more accurately reflects the model's failure to predict the huge increase in Canadian trade volumes after the Canada-U.S. FTA and NAFTA is a decomposition of the mean squared error, rather than the variance:

$$
\operatorname{msedec}\left(x^{\text {data }}, x^{\text {model }}\right)=\frac{\sum_{i=1}^{n} \alpha_{i}^{2}\left(x_{i}^{\text {model }}\right)^{2}}{\sum_{i=1}^{n} \alpha_{i}^{2}\left(x_{i}^{\text {model }}\right)^{2}+\sum_{i=1}^{n} \alpha_{i}^{2}\left(x_{i}^{\text {data }}\right)^{2}} .
$$

This statistic is the same as our variance decomposition statistic except that it uses uncentered rather than centered - sample moments. Calculating the decomposition of mean squared error, we obtain 0.07 for the prediction of the Cox-Harris model in table 9. It is worth pointing out that the decomposition of squared error usually produces similar results to the decomposition of variance; the results in table 9 are the major exception in this paper. ${ }^{2}$ The point, however, is that we always need to take into account how similar the mean change in the data is to the mean change in the model results when interpreting the decomposition of variance. In this case the regression coefficients provide a better indicator of how far off the predictions are: The best that

\footnotetext{
${ }^{2}$ For results like those reported in table 1 , where the weighted mean of the changes is equal to 0 , the two measures are, of course, identical.
} 
we can do with the small predictions in trade patterns to match the large changes that occurred is to multiply them by 1.93 and then add 39.40 percent to each.

The predictions of the Cox-Harris model for overall trade by sector in table 10 are fairly accurate in terms of relative magnitudes. The model correctly predicted that exports of machinery and appliances would increase more than average and that imports of transportation equipment would increase less than average. The variance decomposition statistics show that the model did not do as well in predicting the increase in Canadian trade. At first glance, we might be tempted to conclude from comparing table 10 with tables 6,7 , and 8 that the Cox-Harris model was more successful than the Brown-Deardorff-Stern model in predicting changes in sectoral trade. It is probably the case that it is far more difficult to predict changes in bilateral trade patterns than changes in overall trade, however, because bilateral trade by sector seems to be far more volatile.

Table 11 compares changes in the data with the results of a numerical experiment of the Sobarzo model that eliminated Mexican tariffs and allowed capital inflows into Mexico. In this experiment, Mexico ran a substantial trade deficit, reflected in the results in table 11, where increases in imports are much larger than increases in exports. The predictions of the model for relative changes in exports are fairly accurate, as reflected in the weighted correlation coefficient of 0.61. In particular, the model predicted the observed increase in exports of electrical machinery relative to GDP and the decrease in mining (which is mostly petroleum in the case of Mexico). The model was only able to account for a minuscule fraction of the variance of changes in exports, however. The model did not do quite as well in predicting relative changes in imports. In particular, the model failed to predict that imports of mining and nonelectrical machinery would increase less than average. The model was successful, however, in predicting that imports of electrical machinery and transportation equipment would increase more than average. The fraction of the variance of changes in imports accounted for by the model is, once again, minuscule, however.

\section{WHAT DO WE LEARN FROM THESE EVALUATIONS?}

The Spanish model seems to have been far more successful in predicting the consequences of policy changes than the three models of NAFTA evaluated in the previous section. When comparing the predictions of the model of Spain's entry into the EC with those of 
the three NAFTA models, however, we need to keep in mind that the evaluation of the Spanish model by Kehoe, Polo, and Sancho (1995) was carried out by members of the team that had constructed the original model. This implies at least three major differences between their evaluation and the typical evaluation that could be carried out an outsider:

1. Kehoe et al. knew the structure of their model well enough to precisely identify the relationships between the variables in their model and those in the data. Specifically, they knew the concordance between sectors in the data and those in the model. ${ }^{3}$ They were also able to construct variables in the model exactly as the corresponding variables had been constructed in the data. Brown, Deardorff, and Stern (1995) are to be commended for providing a concordance between the sectors in their model and the sectors in the International Standard Industrial Classification (ISIC). The comparisons of model results and data reported in tables 10 and 11 for the Cox-Harris and Sobarzo models, in contrast, are products of concordances produced by the author and reported in the Appendix.

2. Kehoe et al. were able to use the model to carry out numerical exercises to incorporate the impact of exogenous shocks. The importance of being able to do this can be seen by comparing the results in the fourth columns of tables $1-4$ - where both the agricultural productivity shock and the petroleum price shock are included — with the results in the second columns - where only the policy changes associated with entering the EC are taken into account. Without access to the models of NAFTA, it is impossible to provide the results of new numerical experiments for these models.

3. Kehoe et al. had a natural incentive to show their model in the best possible light. The aspect of the evaluation where this incentive probably had the most impact was on the choice of which exogenous shocks to incorporate. It should be noted, however, that the success of the model in predicting the behavior of macroeconomic variables, particularly indirect tax revenues, in table 3 was not significantly altered by the incorporation of these

\footnotetext{
${ }^{3}$ A detailed concordance had already been published by Kehoe, Manresa, Polo, and Sancho (1988).
} 
shocks. The biggest success of the Spanish model was its bottom-line prediction before the policy change took place - that the tax reform was in fact a substantial tax increase. This shows up loudly and clearly in the data. If we take the bottom-line prediction of the three models of NAFTA to be that there would be only modest increases in trade flows, then these models clearly failed. Since trade flows in North America have exploded over the past decade, it is hard to imagine what sorts of exogenous shocks could be incorporated to rectify this failure of the models. ${ }^{4}$

If applied GE analysis is to make progress as a scientific discipline, researchers have to provide access both to the data and to the computer codes needed to calibrate and run their models. Improvements in computer technology have made it far easier to do this using the Internet, in the form of both Web sites and FTP (file transfer protocol) sites, than it was over a decade ago when the models of NAFTA were being developed. This sort of access would allow other researchers to carry out evaluations that would eliminate at least the first two discrepancies discussed above. Modelers should also feel it incumbent on themselves to carry out this sort of evaluation of their own models. Otherwise, if any evaluations are to be done at all, they will necessarily be done by researchers with less incentive to show their models in a good light.

Comparing the evaluation of the model of Spain's entry into the EC with those of the models of NAFTA, we can speculate about why the Spanish model was more successful. It may be that we, as economists, understand public finance issues better than we do international trade. It may also be that applied GE models do a better job of making predictions over time horizons of one or two years than they do of making predictions over time horizons as long as a decade. Fox (1999) carries out a performance evaluation of the Brown-Stern (1989) model of the Canada-U.S. FTA using data from the period 1988-1992 and obtains somewhat more favorable results than we are able to in the previous section for the models of NAFTA. Fox has the advantage of being able to run numerical experiments of the Brown-Stern model with partial tariff reductions to account for phased-in tariff reductions that had taken place by 1992 . Given

\footnotetext{
${ }^{4}$ It should be noted that Burfisher, Robinson, and Thierfelder (2001) cast a more favorable light on predictions made by applied GE models of NAFTA, although they do not perform the sort of systematic comparison of model results with the data as that reported in the previous section. They focus more on predictions of macroeconomic variables like unemployment and trade deficits, pointing out that the models predicted little change in these variables.
} 
that NAFTA is scheduled to be phased in over 15 years, that the published results of the models incorporate the complete set of policy changes, and that we cannot run new numerical experiments of the models to incorporate partial changes, we are forced to use a long time horizon. Once again, this is the sort of limitation that would be eliminated by access to the model's data and computer codes. In any case, to test the speculative hypotheses that we have made, far more research comparing model results with data is needed.

\section{SECTORAL DETAIL: WHAT DRIVES INCREASES IN TRADE?}

The evaluation of the performances of the models of NAFTA suggests that we need to reexamine the theoretical mechanisms that drive increases in trade in applied GE models. The Brown-Deardorff-Stern, Cox-Harris, and Sobarzo models all rely on "New Trade Theory" mechanisms in which trade is driven by the Dixit-Stiglitz (1977) taste for variety specification, either in utility functions or in production functions. Bergoeing and Kehoe (1999) and Yi (2003) argue that these sorts of models cannot account for the large increases in international trade observed since the end of World War II.

The basic problem is that the taste for variety specification led the three models of NAFTA to predict that the largest increases in trade would occur in sectors in which there already is significant trade. The Dixit-Stiglitz (1977) specification of taste for variety says that inputs of goods, into either consumption or production, from the same sector but from different firms, are close, but not perfect, substitutes. In theoretical models, the typical functional form is

$$
x_{i}=\theta_{i}\left(\sum_{j=1}^{n_{i}} x_{i, j}^{\rho}\right)^{1 / \rho}
$$

where $x_{i}$ is the effective input from sector $i, n_{i}$ is the total number of firms in sector $i$ in the whole world, $x_{i, j}$ is the input from firm $j, \theta_{i}>0$, and $1>\rho>0$. A problem well understood by trade economists in calibrating models with this sort of taste for variety is that of home country bias. For reasonable values of the substitution parameter $\rho$, the model predicts far too much trade given observed trade barriers and transportation costs. To get around this problem, calibrated models typically modify the taste for variety function. In Mexico, for example, the effective value of inputs from sector $i$ would be 


$$
x_{i}^{\text {mex }}=\theta_{i}\left(\alpha_{i, \text { man }}^{\text {mex }} \sum_{j=1}^{n_{i, c a n}} x_{i, j, \text { can }}^{\rho}+\alpha_{i, \text { mex }}^{\text {mex }} \sum_{j=1}^{n_{i, \text { mex }}} x_{i, j, \text { mex }}^{\rho}+\alpha_{i, u s}^{\operatorname{mex}} \sum_{j=1}^{n_{i, u s}} x_{i, j, u s}^{\rho}+\alpha_{i, r w}^{\operatorname{mex}} \sum_{j=1}^{n_{i, w}} x_{i, j, r w}^{\rho}\right)^{1 / \rho},
$$

where inputs are differentiated not just by firm but by country of origin - Canada, Mexico, the United States, or the rest of the world. The parameters $\alpha_{i, c a n}^{\text {mex }}, \alpha_{i, u s}^{\text {mex }}, \alpha_{i, r w}^{\text {mex }}$ are smaller than $\alpha_{i, \text { mex }}^{\text {mex }}$ and are calibrated to base year trade flows. (See Kehoe and Kehoe 1995 for details.) This calibration goes a long way in locking in trade patterns of the model. If base-year Canadian exports of good $i$ to Mexico are very small, for example, then $\alpha_{i, c a n}^{\operatorname{mex}}$ is calibrated to be very small, and even large changes in trade barriers would have little effect on these trade flows. Yi (2003) proposes a model, based on Dornbusch, Fischer, and Samuelson's (1977) Ricardian model with a continuum of goods, in which there are large increases in trade in goods not previously traded. Before studying how a Ricardian model can generate large increases in trade in new categories of goods, we look at data to answer the question: In which sectors did the large increases in trade associated with NAFTA occur? In those sectors already heavily traded? Or in those sectors with little or no trade before NAFTA?

To answer these questions both for NAFTA and for a large number of other trade liberalization episodes, Kehoe and Ruhl (2002) perform the following data exercise. They take four-digit Standard International Trade Classification (SITC, Revision 2) bilateral trade data obtained from the Organisation for Economic Co-operation and Development (OECD). There are 789 categories of goods in these data. First, they rank categories in order of base year exports, from categories with the smallest amount of trade to the categories with the largest amount. Second, they form 10 sets of categories by cumulating exports — the first 741.3 categories account for 10 percent of exports, for example; the next 24.4 categories account for 10 percent of exports; the next 9.9 categories account for 10 percent of exports; and so on. Third, they calculate the share of exports in subsequent years accounted for by each set of categories. Figures 1-4 show the results of this exercise for trade between Canada and Mexico over the period 1988-1999. What stands out in both figure 1 and figure 2 is that the largest increases in the share of exports occur for those sets of categories that accounted for the smallest amount of trade in 1988. The 741.3 smallest categories of exports from Canada to Mexico accounted for 10 
percent of exports in 1988, but in 1999 these same 741.3 categories accounted for 34.6 percent of exports.

There were some spectacular increases in the shares of exports from Canada to Mexico in some individual categories in the set with the smallest exports in 1988. Exports of Motor Cars for Transport of Passengers and Goods (7810), for example, went from 0.01 percent of Canada's exports to Mexico in 1988 to 5.06 percent in 1999; Meat of Bovine Animals, Fresh, Chilled or Frozen (0111) went from 0.08 percent to 2.28 percent; and Aluminum and Aluminum Alloys, Unwrought (6841) went from 0 percent to 1.33 percent.

Focusing only on the categories with these spectacular increases gives a misleading impression, however. If we eliminate the categories with the largest increases, we see that there were a very large number of categories in which Canada went from exporting little or nothing in 1988 to exporting significant amounts in 1999.

Eliminating the 10 categories that accounted for the most trade in 1999 of the 741.3 smallest categories in 1988, we are left with 731.3 categories that accounted for 6.2 percent of exports in 1988, but 16.6 percent in 1999. Coated/Impregnated Textile Fabrics and Products (6573), for example, went from 0.05 percent of Canada's exports to Mexico in 1988 to 0.48 percent in 1999; Polystyrene and its Copolymers (5833) went from 0 percent to 0.22 percent; and Cheese and Curd (0240) went from 0 percent to 0.09 percent.

At the other end of the list of categories, some categories that accounted for large shares of exports in 1988 saw their shares increase in 1999. Other Parts and Accessories of Motor Vehicles (7849), for example, increased from 10.25 percent of exports to 16.85 percent (accounting for the large increase in the share of the 0.8-0.9 set of categories in 1988 in figure 1); and Newsprint (6411) increased from 1.35 percent to 1.55 percent. On the whole, however, those categories that accounted for the largest shares of exports in 1988 saw their shares decline by 1999. These tendencies help account for the dismal failure of the Brown-Deardorff-Stern model to predict the pattern of changes in sectoral trade in table 6.

Figure 2, which depicts the change in composition of Mexican exports to Canada over the period 1988-1999, shows much the same pattern as figure 1. The set of least traded categories in 1988 has the largest increase in export share by 1999. A striking difference between figure 1 and figure 2 is the large jump in the share of exports of the $0.2-0.3$ set of categories in figure 3 . This increase in share is completely accounted for by one category, Motor Cars for Transport of 
Passengers and Goods (7810), whose exports went from 0.76 percent of Mexican exports to Canada in 1988 to 15.02 percent in 1999.

Figures 3 and 4 show the evolution over the period 1988-1999 of the export shares of the set of categories least traded in 1988. What is worth noting is how these shares increase gradually over time. (Kehoe and Ruhl 2002 show that this sort of pattern of increase does not occur for bilateral trade between countries that have not undergone significant trade liberalization.) It is also interesting to note the more volatile nature of the patterns of trade in exports from Canada to Mexico in figure 3, perhaps due to more volatile macroeconomic conditions in Mexico, especially the 1995 crisis. That the change in trade patterns should take place gradually over time is partly to be expected given the nature of gradual trade liberalization in Mexico before the implementation of NAFTA and the timed phasing out of trade barriers under NAFTA. Nonetheless, figures 3 and 4 suggest that the impact of trade liberalization on trade patterns takes place over time. Once again, we see the need for a dynamic model to analyze the impact of trade liberalization. We also have a potential reconciliation of the relatively poor evaluation that we produce for the Brown-Deardorff-Stern model of NAFTA, even for bilateral Canada-U.S. trade, with Fox's (1999) more favorable evaluation of the earlier version of this model that had focused on the Canada-U.S. FTA. It may be that Fox, who only looks at data over the period 1988-1992, does not use a long enough time horizon to capture the full effects of the Canada-U.S. FTA.

To see how a Ricardian model can capture large increases in trade in categories or sectors with little or no trade in the base period, consider a model with a continuum of goods $x \in[0,1]$. The production technologies in the home and foreign countries are $y(x)=\ell(x) / a(x)$ and $y^{*}(x)=\ell^{*}(x) / a^{*}(x)$, where the unit labor requirement functions $a(x)$ and $a^{*}(x)$ are continuous. Assume that the two countries impose uniform ad valorem tariffs $\tau, \tau$ *

If

$$
\begin{gathered}
\left(1+\tau^{*}\right) w a(x)<w^{*} a^{*}(x) \\
\frac{a(x)}{a^{*}(x)}<\frac{w^{*}}{\left(1+\tau^{*}\right) w},
\end{gathered}
$$


then the home country produces good $x$ and exports it to the foreign country, which does not produce the good. Similarly, if

$$
\frac{a(x)}{a^{*}(x)}>\frac{(1+\tau) w^{*}}{w}
$$

then the foreign country produces good $x$ and exports it to the home country, which does not produce the good. Notice that

$$
\frac{w^{*}}{\left(1+\tau^{*}\right) w}<\frac{a(x)}{a^{*}(x)}<\frac{(1+\tau) w^{*}}{w}
$$

implies that both countries produce good $x$, which is not traded. Lowering tariffs can generate trade in previously nontraded goods.

In their exposition, Dornbusch, Fischer, and Samuelson (1977), proposed reordering the goods on the interval $[0,1]$ in order of increasing comparative advantage for the home country, that is, so that the ratio of unit labor requirements $a(x) / a^{*}(x)$ is a non-increasing function of the name of the good $x$. Textbook expositions of the Ricardian model have followed this convention ever since. In contrast, Kehoe and Ruhl (2002) propose leaving the goods on the interval in the same order that the SITC would order them if this classification could be done to an arbitrarily high number of digits. A four-digit SITC category is now an interval on the line as depicted in figure 5. (Figure 5 is only meant to represent a subset of the interval $[0,1]-$ remember that we have 789 categories.) The curve that represents the ratio of unit labor requirements $a(x) / a^{*}(x)$ and determines trade patterns is now more arbitrary. Notice how, for the curve drawn in figure 5, there are categories like the shaded one where reducing trade barriers in the form of the tariffs $\tau, \tau *$ generates huge increases in trade where there was little or none before.

Kehoe and Ruhl (2002) propose and calibrate a method for generating relative-unit-laborrequirement functions $a(x) / a^{*}(x)$, and they argue that this sort of model can go a long way in explaining the sorts of changes in trade patterns we see in figures 1 and 2. All of their analysis maintains the assumption of uniform trade barriers across goods. Romalis (2002) demonstrates 
that differences across sectors in changes in trade barriers were important in determining changes in trade patterns after NAFTA. This point is not necessarily relevant to our argument that we need models that generate large increases in trade in categories or sectors where there had been little or no trade, however: Kehoe and Ruhl (2002) demonstrate that the distribution of reductions in trade barriers within the set of categories with the least trade in 1988 was not noticeably different from the distribution of the reduction in trade barriers for all other categories. Obviously, much work is needed before any conclusions can be drawn.

\section{BIG QUESTION: WHAT DRIVES CHANGES IN PRODUCTIVITY?}

The papers in the volume edited by Kehoe and Prescott (2002) employ a simple applied GE methodology for analyzing the causes of large macroeconomic fluctuations, specifically the great depressions that occurred in Europe and North America in the 1920s and '30s, in Latin America in the 1980s, and in Japan in the 1990s. Using this methodology, we can determine whether economic fluctuations are caused by changes in inputs of labor, by changes in inputs of capital, or by changes in the efficiency with which these factors are used, measured as total factor productivity. Bergoeing, Kehoe, Kehoe, and Soto (2002) study the great depressions that began in Chile and Mexico in the early 1980s and the radically different recovery paths that these two countries followed afterward, with Chile growing rapidly and Mexico mired in crisis or stagnation until 1995. Bergoeing et al. conclude that the differences in the recovery paths of Chile and Mexico were primarily due to differences in the paths of total factor productivity rather than to differences in their rates of employment or investment. They hypothesize that these different productivity paths were due to Chile's earlier reforms in banking and bankruptcy procedures, which encouraged a distribution of firms with higher productivity than that of the distribution of firms in Mexico. In both countries, fiscal reforms in the mid to late 1980s led to an increase in investment rates, but this increased both recovery paths rather than causing the two paths to differ.

The research of Bergoeing et al. has an obvious general relevance for applied GE analysis of the impact of NAFTA. In line with the theme of this paper, however, we focus the relevance very tightly as a challenge to modelers of the impact of NAFTA: We use a simple aggregate, dynamic GE model to show that, if we can successfully model the determinants of total factor productivity, then we understand the determinants of most of the macroeconomic fluctuations 
that occurred in Mexico over the period 1988-2002. The changes in trade flows and foreign investment associated with NAFTA are relevant to the extent that they help us determine productivity, not employment or - surprisingly — even investment. To make the point bluntly and perhaps a little too crudely, if NAFTA was not important for total factor productivity in Mexico, then it was not important in determining macroeconomic fluctuations there.

It is worth pointing out that Trefler (2001) finds that a major impact of the Canada-U.S. FTA on Canada was in changing the distribution of firms in terms of size and productivity. Trefler also argues that the change in the distribution of firms that occurred in Canada did not match the predictions of applied GE models - like the three models of NAFTA that we have examined — that relied on the Dixit-Stiglitz (1977) theory of industrial organization.

We modify the simple, one-sector, closed economy model of Bergoeing, Kehoe, Kehoe, and Soto (2002) to include fluctuations in the trade balance. ${ }^{5}$ The aggregate feasibility constraint in this economy is

$$
C_{t}+K_{t+1}-(1-\delta) K_{t}+X_{t}=A_{t} K_{t}^{\alpha} L_{t}^{1-\alpha}
$$

Here $C_{t}$ is aggregate consumption, both private and public, measured in constant pesos; $K_{t}$ is capital; $K_{t+1}-(1-\delta) K_{t}$ is gross investment; $\delta K_{t}$ is depreciation; $X_{t}$ is the trade balance; and $L_{t}$ is the labor input measured in hours worked per year. Following Bergoeing et al., we set $\delta=0.05$ and cumulate investment to calculate the path for the capital stock,

$$
K_{t+1}=I_{t}+(1-\delta) K_{t}
$$

and then set $\alpha=0.30$ to calculate the path for total factor productivity,

$$
A_{t}=\frac{C_{t}+K_{t+1}-(1-\delta) K_{t}+X_{t}}{K_{t}^{\alpha} L_{t}^{1-\alpha}}=\frac{Y_{t}}{K_{t}^{\alpha} L_{t}^{1-\alpha}}
$$

\footnotetext{
${ }^{5}$ See Bergoeing et al. (2002) for details. We also extend their analysis to cover 2001 and 2002 and employ improved estimates of hours worked in Mexico.
} 
We now consider a simple dynamic model in which we take fluctuations in total factor productivity $A_{t}$ as exogenous. The point is not that we as applied GE modelers should want to take productivity as exogenous. In fact, the point is exactly the opposite: If a model with $A_{t}$ treated as exogenous accounts for most macroeconomic fluctuations, then we know that it is changes in $A_{t}$ that we need to be able to explain!

The stand-in consumer chooses sequences of consumption, capital, and hours worked to maximize

$$
\sum_{t=1980}^{\infty} \beta^{t}\left[\gamma \log C_{t}+(1-\gamma) \log \left(\bar{h} N_{t}-L_{t}\right)\right]
$$

subject to the budget constraint in each period,

$$
C_{t}+K_{t+1}-K_{t}=w_{t} L_{t}+\left(1-\tau_{t}\right)\left(r_{t}-\delta\right) K_{t}+T_{t}-X_{t}
$$

and an initial condition on capital, $K_{1988}$. Here $\bar{h}$ is the number of hours available, taken to be 100 hours per week, 52 weeks per year for working-age (15-64) persons; $N_{t}$ is the population aged 15-64; and $\left(\bar{h} N_{t}-L_{t}\right)$ is leisure. In addition, $r_{t}$ and $w_{t}$ are the marginal products of the production function with respect to $K_{t}$ and $L_{t} ; \tau_{t}$ is the income tax rate on capital income; and $T_{t}$ is a lump-sum transfer that in equilibrium is equal to tax revenue $\tau_{t}\left(r_{t}-\delta\right) K_{t}$.

Using the first-order condition for the labor-leisure decision from the stand-in consumer's problem, we follow Bergoeing et al. in using 1960-1980 data to estimate $\gamma=0.30$. Setting $\beta=0.98$, we use the first-order condition for the consumption-investment decision to estimate a tax distortion $\tau_{t}=0.43$.

Figures 6-9 present the results of numerical experiments in which the sequences of $A_{t}$ and $X_{t}$ are treated as exogenous. The panel in the upper left of each figure shows the time paths 
for output per working aged person $Y_{t} / N_{t}$, the capital-output ratio $K_{t} / Y_{t}$, and hours worked per working aged person $L_{t} / N_{t}$ (measured in hours per week) for the base case numerical experiment. Bergoeing et al. argue that the failure of the model to track the paths of these macroeconomic variables is due to its neglect of fiscal reforms in 1987 and 1989 that lowered the effective tax on capital income. They estimate that these reforms had the effect of lowering the tax distortion to $\tau_{t}=0.12$. The panel in the lower right of each figure shows the time paths of the variables in the numerical experiment that incorporates this tax reform.

The excellent performance of the model in tracking the macroeconomic variables should not be interpreted as saying that the fiscal reforms were the only major determinants of macroeconomic fluctuations. Remember that we still need to explain the path of total factor productivity! Comparing the results of the numerical experiments in the lower right with the remaining two numerical experiments emphasizes the point that it is productivity that we need to understand if we are to understand macroeconomic fluctuations: The panels in the upper right of each graph present the results of the experiment in which we restrict the trade balance to be constant at its average value over the period 1988-2002. Notice that this restriction has almost no effect at all on the results except for its impact on investment. The fluctuations in foreign capital flows increase investment in figure 9 during the early 1990s and then lower it sharply in 1995. That foreign capital flows have almost no other effect in this simple one-sector model does not imply that fluctuations in foreign investment and the trade balance were not important in determining macroeconomic fluctuations in Mexico over the period 1988-2002. As Fernández de Córdoba and Kehoe (2000) show, these sorts of fluctuation have large effects on relative prices and the allocation of resources across traded and nontraded goods sectors. It is just that whatever impact these fluctuations have at a macroeconomic level work through fluctuations in productivity rather than through fluctuations in aggregate employment or investment.

The numerical experiment whose results are depicted in the panels in the lower left of each figure further emphasizes the importance of fluctuations in productivity rather than fluctuations in the trade balance. Here we model total factor productivity as following its trend growth path, and we lose almost all ability to account for fluctuations, even though we still incorporate fluctuations in the trade balance into the model. If we have total factor productivity follow a different growth rate, we produce time paths for the macroeconomic variables that differ 
even more from the data. Once again, we are stressing the point that, if capital flows into Mexico are to have important effects on macro aggregates, then these effects have to operate through productivity and not just by loosening the feasibility constraint or altering aggregate employment or investment.

\section{CHALLENGE}

In this article, I have tried to challenge applied GE modelers to do a better job. After a policy change like NAFTA has taken place, we need to go back and to see how well the predictions of our models have fared. Making predictions with deterministic models in a world with uncertainty is difficult. An easy way out of this difficulty is to say that predictions are meant to hold ceteris paribus and to assert that everything was not equal, especially in Mexico, where a major financial crisis occurred the year after NAFTA went into effect. What is more difficult is to go back and to identify exactly what exogenous parameter changes need to be imposed on a model so that it can reproduce what actually happened. The less plausible these parameter changes, the less plausible the original predictions.

It is my conjecture that no plausible parameter changes can get the models of NAFTA built on the Dixit-Stiglitz specification to match what actually has happened in North America. Simply imposing large elasticities of substitution between different types of goods in a sector is capable of generating large increases in trade flows in response to tariff changes, but it is likely to do so in the wrong sectors. Modelers are also likely to find high elasticities of substitutions unattractive and/or implausible for other reasons. High elasticities of substitution imply that trade liberalization has very small welfare consequences, for example. Furthermore, in international real business cycle models, such high elasticities imply implausibly large volatilities of the trade balance. In any case, it is the responsibility of modelers to demonstrate that their models are capable of predicting observed changes, at least ex post. If a modeling approach is not capable of reproducing what has happened, we should discard it. I further conjecture that the biggest effect of liberalization of trade and capital flows is the effect on productivity - through changing the distribution of firms and encouraging technology adoption — rather than the effects emphasized by the models used to analyze the impact of NAFTA.

Much is at stake both in terms of scientific disciple and in terms of policy analysis. During the political debate prior to approval of NAFTA by the U.S. Congress, American 
businessman and politician Ross Perot criticized the same models of NAFTA that we have analyzed in this paper, saying,

[T] hese studies are based on unrealistic assumptions and flawed mathematical models...Let's be clear about this: these studies certainly do not provide a basis on which Congress can make an informed decision about NAFTA. [Perot with Choate, 1993, 66-67.]

We economists can comfort ourselves by observing that his own predictions of the impact of NAFTA on the U.S. economy turned out to be far less accurate than that of the models that he criticized. Nevertheless, as researchers in a scientific discipline, we need to build on our past shortcomings and strive to build better models to use in the future. 


\section{REFERENCES}

Adams, P., P. Dixon, D. McDonald, G. Meagher, and B. Parmenter (1994), "Forecasts for the Australian Economy Using the MONASH Model," International Journal of Forecasting, $10,557-571$.

Arrow, K. J., and G. Debreu (1954), "Existence of Equilibrium for a Competitive Economy," Econometrica, 22, 265-290.

Bergoeing, R., P. J. Kehoe, T. J. Kehoe, and R. Soto (2002), “A Decade Lost and Found: Mexico and Chile in the 1980s," Review of Economic Dynamics, 5, 166-205.

Bergoeing, R. and T. J. Kehoe (1999), “Trade Theory and Trade Facts,” Federal Reserve Bank of Minneapolis.

Brown, D. K. (1992), "Properties of Computable General Equilibrium Trade Models with Monopolistic Competition and Foreign Direct Investment," in United States International Trade Commission, Economy-Wide Modeling of the Economic Implications of a FTA with Mexico and a NAFTA with Canada and Mexico, Washington, DC: United States International Trade Commission, 95-125.

Brown, D. K. (1994), "Properties of Computable General Equilibrium Trade Models with Monopolistic Competition and Foreign Direct Investment," in J. F. Francois and C. R. Shiells, editors, Modeling Trade Policy: Applied General Equilibrium Assessments of North American Free Trade, New York: Cambridge University Press, 124-150.

Brown, D. K., A. V. Deardorff, and R. M. Stern (1992), “A North American Free Trade Agreement: Analytical Issues and a Computational Assessment," The World Economy, $15,11-30$.

Brown, D. K., A. V. Deardorff, and R. M. Stern (1995), "Estimates of a North American Free Trade Agreement," in P. J. Kehoe and T. J. Kehoe, editors, Modeling North American Economic Integration, Boston: Kluwer Academic Publishers, 59-74.

Brown, D. K., and R. M. Stern (1989), "Computable General Equilibrium Estimates of the Gains from U.S.-Canadian Trade Liberalization," in R. C. Feenstra, editor, Trade Policies for International Competitiveness, Chicago: University of Chicago Press, 217-245.

Burfisher, M. E., S. Robinson, and K. Thierfelder (2001), “The Impact of NAFTA on the United States," Journal of Economic Perspectives, 15, 125-144. 
Cox, D. J. (1994), “Some Applied General Equilibrium Estimates of the Impact of a North American Free Trade Agreement on Canada," in J.F. Francois and C.R. Shiells, editors, Modeling Trade Policy: Applied General Equilibrium Assessments of North American Free Trade, New York: Cambridge University Press, 100-123.

Cox, D. J. (1995), “An Applied General Equilibrium Analysis of NAFTA’s Impact on Canada,” in P.J. Kehoe and T.J. Kehoe, editors, Modeling North American Economic Integration, Boston: Kluwer Academic Publishers, 75-90.

Cox, D. J. and R. G. Harris (1985), “Trade Liberalization and Industrial Organization: Some Estimates for Canada," Journal of Political Economy, 93, 115-145.

Cox, D. J. and R. G. Harris (1992a), "North American Free Trade and its Implications for Canada," in United States International Trade Commission, Economy-Wide Modeling of the Economic Implications of a FTA with Mexico and a NAFTA with Canada and Mexico, Washington, DC: United States International Trade Commission, 139-165.

Cox, D. J. and R. G. Harris (1992b), "North American Free Trade and its Implications for Canada: Results from a CGE Model of North American Trade," The World Economy, 15, $31-44$.

Dervis, K., J. de Melo, and S. Robinson (1982), General Equilibrium Models for Development Policy, Cambridge: Cambridge University Press.

Dixit, A. K., and J. E. Stiglitz (1977), "Monopolistic Competition and Optimum Product Diversity," American Economic Review, 67, 297-308.

Dornbusch, R., S. Fischer, and P. A. Samuelson (1977), “Comparative Advantage, Trade and Payments in a Ricardian Model with a Continuum of Goods," American Economic Review, 67, 823-829.

Fernández de Córdoba, G. and T. J. Kehoe (2000), "Capital Flows and Real Exchange Rate Movements Following Spain's Entry into the European Community,” Journal of International Economics, 51, 49-78.

Fox, A. K. (1999), "Evaluating the Success of a CGE Model of the Canada-U.S. Free Trade Agreement," University of Michigan.

Francois, J. F. and C. R. Shiells, editors (1994), Modeling Trade Policy: Applied General Equilibrium Assessments of North American Free Trade, New York: Cambridge University Press. 
Harberger, A. C. (1962), “The Incidence of the Corporate Income Tax,” Journal of Political Economy, 70, 215-240.

Harris, R. (1984), “Applied General Equilibrium Analysis of Small Open Economies with Scale Economies and Imperfect Competition," American Economic Review, 74, 1016-1032.

Johansen, L. (1960), A Multi-Sectoral Study of Economic Growth, Amsterdam: North Holland. Kehoe, P. J., and T. J. Kehoe, editors (1995), Modeling North American Economic Integration, Boston: Kluwer Academic Publishers.

Kehoe, T. J. (1992), "Modeling the Dynamic Impact of North American Free Trade," in Economy-Wide Modeling of the Economic Implications of an FTA with Mexico and a NAFTA with Canada and the United States, United States International Trade Commission Publication 2508, 249-276.

Kehoe, T. J., A. Manresa, P. J. Noyola, C. Polo, and F. Sancho (1988), “A General Equilibrium Analysis of the 1986 Tax Reform in Spain," European Economic Review, 32, 334-342.

Kehoe, T. J., A. Manresa, P. J. Noyola, C. Polo, F. Sancho, and J. Serra-Puche (1985), Modelos de Equilibrio General Aplicado (MEGA): Un Análisis del Impacto del Impuesto sobre el Valor Añadido (IVA) sobre la Economía Española, Madrid: Instituto de Estudios Fiscales.

Kehoe, T. J., A. Manresa, P. J. Noyola, C. Polo, F. Sancho, and J. Serra-Puche (1986a), “A General Equilibrium Analysis of the Indirect Tax Reform in Spain," Working Paper 66.86, Departament d'Economia i d'Història Econòmica, Universitat Autònoma de Barcelona.

Kehoe, T. J., A. Manresa, P. J. Noyola, C. Polo, F. Sancho, and J. Serra-Puche (1986b), “A Social Accounting System for Spain: 1980," Working Paper 63.86, Departament d'Economia i d'Història Econòmica, Universitat Autònoma de Barcelona.

Kehoe, T. J., A. Manresa, P. J. Noyola, C. Polo, F. Sancho, and J. Serra-Puche (1986c), "Política Econòmica i Equilibri General. Quins són els Efectes de l'IVA?" Revista Econòmica de Catalunya, 2, 76-81.

Kehoe, T. J., A. Manresa, C. Polo, F. Sancho (1988), "Una Matriz de Contabilidad Social de la Economía Española," Estadística Española, 30, 5-33.

Kehoe, T. J., A. Manresa, C. Polo, F. Sancho (1989), “Un Análisis de Equilibrio General de la Reforma Fiscal de 1986 en España,” Investigaciones Económicas, 13, 337-385. 
Kehoe, T. J., C. Polo, F. Sancho (1995), “An Evaluation of the Performance of an Applied General Equilibrium Model of the Spanish Economy," Economic Theory, 6, 115-141.

Kehoe, T. J. and E.C. Prescott (2002), "Great Depressions of the 20th Century," special issue of Review of Economic Dynamics, 5.

Kehoe, T. J. and K. J. Ruhl (2002), "How Important is the New Goods Margin in International Trade?" Federal Reserve Bank of Minneapolis.

Krugman, P. R. (1979), "Increasing Returns, Monopolistic Competition, and International Trade," Journal of International Economics, 9, 469-479.

Leontief, W. W. (1941), Input-Output Economics, New York: Oxford University Press.

McKenzie, L. (1959), "On the Existence of General Equilibrium for a Competitive Market," Econometrica, 27, 54-71.

Nicita, A. and M. Olarreaga (2001), “Trade and Production, 1976-1999,” The World Bank. (www.worldbank.org/research/trade.)

Perot, R. with P. Choate (1993), Save Your Job, Save Our Country: Why NAFTA Must Be Stopped - Now! New York: Hyperion.

Romalis, J. (2002), “NAFTA's and CUSFTA's Impact on North American Trade," University of Chicago.

Scarf, H. E. (1967), "On the Computation of Equilibrium Prices," in W.J. Feller, editor, Ten Economic Studies in the Tradition of Irving Fisher, New York: Wiley, 207-230.

Scarf, H. E., with the collaboration of T. Hansen (1973), The Computation of Economic Equilibria, New Haven: Yale University Press.

Shiells, C. R. and R. C. Shelburne (1992), "A Summary of "Industrial Effects of a Free Trade Agreement Between Mexico and the United States," in United States International Trade Commission, Economy-Wide Modeling of the Economic Implications of a FTA with Mexico and a NAFTA with Canada and Mexico, Washington, DC: United States International Trade Commission, 5-19.

Shoven, J. B. and J. Whalley (1973), "General Equilibrium with Taxes: A Computational Procedure and an Existence Proof," Review of Economic Studies, 40, 475-489. 
Sobarzo, H. (1992a), "A General Equilibrium Analysis of the Gains from Trade for the Mexican Economy of a North American Free Trade Agreement," in United States International Trade Commission, Economy-Wide Modeling of the Economic Implications of a FTA with Mexico and a NAFTA with Canada and Mexico, Washington, DC: United States International Trade Commission, 599-653.

Sobarzo, H. (1992b), "A General Equilibrium Analysis of the Gains from Trade for the Mexican Economy of a North American Free Trade Agreement," The World Economy, 15, 83100.

Sobarzo, H. (1994), "The Gains from Trade for the Mexican Economy of a North American Free Trade Agreement - An Applied General Equilibrium Assessment," in J. F. Francois and C. R. Shiells, editors, Modeling Trade Policy: Applied General Equilibrium Assessments of North American Free Trade, New York: Cambridge University Press, 83-99.

Sobarzo, H. (1995), "A General Equilibrium Analysis of the Gains from NAFTA for the Mexican Economy," in P.J. Kehoe and T.J. Kehoe, editors, Modeling North American Economic Integration, Boston: Kluwer Academic Publishers, 91-116.

Trefler, D. (2001), “The Long and Short of the Canada-U.S. Free Trade Agreement,” University of Toronto.

United States International Trade Commission (1992), Economy-Wide Modeling of the Economic Implications of a FTA with Mexico and a NAFTA with Canada and Mexico, Washington, DC: United States International Trade Commission.

Yi, K.-M. (2003), “Can Vertical Specialization Explain the Growth of World Trade?” Journal of Political Economy, 111, 52-102. 


\section{APPENDIX}

Data on Gross Domestic Product (GDP) and exchange rates are taken from the International Monetary Fund's International Financial Statistics. A country's U.S. dollar GDP is calculated by dividing GDP denominated in local currency by the yearly average dollar exchange rate. Data on total trade by country are from the International Monetary Fund's Direction of Trade Statistics.

Data on trade in manufactures are taken from the World Bank's Trade and Production Database. The database contains bilateral trade flow data reported according to the International Standard Industrial Classification (ISIC) at the three- and four-digit level for manufactured goods. The World Bank created the ISIC data by converting data from the Standard International Trade Classification (SITC) using a concordance created by the OECD and provided by the World Bank (see Nicita and Olarreaga 2001).

Since the World Bank database does not provide data for non-manufactures, the data for ISIC major divisions 1 and 2 need to be calculated by converting SITC trade data to ISIC. We obtain data on trade classified by SITC from the OECD's International Trade by Commodity Statistics Database. We derive a concordance from SITC to ISIC major divisions 1 and 2 from the OECD concordance as follows: After using the OECD concordance to extract the manufacturing data from the SITC trade flows, the residual SITC data contain the trade in agricultural products, fishing, and mining and quarrying. We make the concordance from SITC to ISIC major divisions 1 and 2 by assigning the residual values of SITC sections $0,1,2$, and 3 to the appropriate divisions and major groups of ISIC major divisions 1 and 2. The resulting concordance is displayed in table A1.

Tables 10 and 11 require data mapped from the ISIC aggregation into the aggregates in the Cox-Harris and Sobarzo models. The concordances used are listed in tables A2 and A3. 


\section{Table 1}

\section{Changes in Consumer Prices Relative to CPI in the Spanish Model}

(Percent)

\begin{tabular}{lrrrr}
\hline & $\begin{array}{c}\text { data } \\
\text { 1985-1986 }\end{array}$ & $\begin{array}{c}\text { model } \\
\text { policy only }\end{array}$ & $\begin{array}{c}\text { model } \\
\text { shocks only }\end{array}$ & $\begin{array}{c}\text { model } \\
\text { policy \& shocks }\end{array}$ \\
\hline food and nonalcoholic beverages & 1.8 & -2.3 & 4.0 & 1.7 \\
tobacco and alcoholic beverages & 3.9 & 2.5 & 3.1 & 5.8 \\
clothing & 2.1 & 5.6 & 0.9 & 6.6 \\
housing & -3.3 & -2.2 & -2.7 & -4.8 \\
household articles & 0.1 & 2.2 & 0.7 & 2.9 \\
medical services & -0.7 & -4.8 & 0.6 & -4.2 \\
transportation & -4.0 & 2.6 & -8.8 & -6.2 \\
recreation & -1.4 & -1.3 & 1.5 & 0.1 \\
other services & 2.9 & 1.1 & 1.7 & 2.8 \\
& & & \\
weighted correlation with data & & -0.08 & 0.87 & 0.94 \\
variance decomposition of change & & 0.30 & 0.77 & 0.85 \\
regression coefficient $\boldsymbol{a}$ & & & & \\
regression coefficient $\boldsymbol{b}$ & & 0.00 & 0.00 & 0.00 \\
\hline
\end{tabular}


Table 2

\section{Changes in Value of Gross Output Relative to GDP in the Spanish Model (Percent)}

\begin{tabular}{lrrrr}
\hline & $\begin{array}{c}\text { data } \\
\text { 1985-1986 }\end{array}$ & $\begin{array}{c}\text { model } \\
\text { policy only }\end{array}$ & $\begin{array}{c}\text { model } \\
\text { shocks only }\end{array}$ & $\begin{array}{c}\text { model } \\
\text { policy \& shocks }\end{array}$ \\
\hline agriculture & -0.4 & -1.1 & 8.3 & 6.9 \\
energy & -20.3 & -3.5 & -29.4 & -32.0 \\
basic industry & -9.0 & 1.6 & -1.8 & -0.1 \\
machinery & 3.7 & 3.8 & 1.0 & 5.0 \\
automobile industry & 1.1 & 3.9 & 4.7 & 8.6 \\
food products & -1.8 & -2.4 & 4.7 & 2.1 \\
other manufacturing & 0.5 & -1.7 & 2.3 & 0.5 \\
construction & 5.7 & 8.5 & 1.4 & 10.3 \\
commerce & 6.6 & -3.6 & 4.4 & 0.4 \\
transportation & -18.4 & -1.5 & 1.0 & -0.7 \\
services & 8.7 & -1.1 & 5.8 & 4.5 \\
government services & 7.6 & 3.4 & 0.9 & 4.3 \\
weighted correlation with data & & & & 0.77 \\
variance decomposition of change & & 0.16 & 0.80 & 0.71 \\
& & 0.11 & 0.73 & -0.52 \\
regression coefficient $\boldsymbol{a}$ & & & & 0.67 \\
regression coefficient $\boldsymbol{b}$ & & -0.52 & -0.52 & 0.75 \\
\hline
\end{tabular}


Table 3

Changes in Composition of GDP and Public Finances in the Spanish Model (Percent of GDP)

\begin{tabular}{|c|c|c|c|c|}
\hline variable & $\begin{array}{c}\text { data } \\
1985-1986\end{array}$ & $\begin{array}{c}\text { model } \\
\text { policy only }\end{array}$ & $\begin{array}{c}\text { model } \\
\text { shocks only }\end{array}$ & $\begin{array}{c}\text { model } \\
\text { policy \& shocks }\end{array}$ \\
\hline wages and salaries & -0.53 & -0.87 & -0.02 & -0.91 \\
\hline business income & -1.27 & -1.63 & 0.45 & -1.24 \\
\hline net indirect taxes and tariffs & 1.80 & 2.50 & -0.42 & 2.15 \\
\hline \multirow{2}{*}{\multicolumn{2}{|c|}{$\begin{array}{l}\text { correlation with data } \\
\text { variance decomposition of change }\end{array}$}} & 0.998 & -0.94 & 0.99 \\
\hline & & 0.93 & 0.04 & 0.96 \\
\hline \multirow{2}{*}{\multicolumn{2}{|c|}{$\begin{array}{l}\text { regression coefficient } a \\
\text { regression coefficient } b\end{array}$}} & 0.00 & 0.00 & 0.00 \\
\hline & & 0.73 & -3.45 & 0.85 \\
\hline private consumption & -0.81 & -1.23 & -0.51 & -1.78 \\
\hline private investment & 1.09 & 1.81 & -0.58 & 1.32 \\
\hline government consumption & -0.02 & -0.06 & -0.38 & -0.44 \\
\hline government investment & -0.06 & -0.06 & -0.07 & -0.13 \\
\hline exports & -3.40 & -0.42 & -0.69 & -1.07 \\
\hline -imports & 3.20 & -0.03 & 2.23 & 2.10 \\
\hline \multirow{2}{*}{\multicolumn{2}{|c|}{$\begin{array}{l}\text { correlation with data } \\
\text { variance decomposition of change }\end{array}$}} & 0.40 & 0.77 & 0.83 \\
\hline & & 0.20 & 0.35 & 0.58 \\
\hline \multirow{2}{*}{\multicolumn{2}{|c|}{$\begin{array}{l}\text { regression coefficient } a \\
\text { regression coefficient } b\end{array}$}} & 0.00 & 0.00 & 0.00 \\
\hline & & 0.87 & 1.49 & 1.24 \\
\hline indirect taxes and subsidies & 2.38 & 3.32 & -0.38 & 2.98 \\
\hline tariffs & -0.58 & -0.82 & -0.04 & -0.83 \\
\hline social security payments & 0.04 & -0.19 & -0.03 & -0.22 \\
\hline direct taxes and transfers & -0.84 & -0.66 & 0.93 & 0.26 \\
\hline government capital income & -0.13 & -0.06 & 0.02 & -0.04 \\
\hline \multirow{2}{*}{\multicolumn{2}{|c|}{$\begin{array}{l}\text { correlation with data } \\
\text { variance decomposition of change }\end{array}$}} & 0.99 & -0.70 & 0.92 \\
\hline & & 0.93 & 0.08 & 0.86 \\
\hline \multirow{2}{*}{\multicolumn{2}{|c|}{$\begin{array}{l}\text { regression coefficient } \boldsymbol{a} \\
\text { regression coefficient } \boldsymbol{b}\end{array}$}} & -0.06 & 0.35 & -0.17 \\
\hline & & 0.74 & -1.82 & 0.80 \\
\hline
\end{tabular}


Table 4

\section{Changes in Trade Flows Relative to GDP in the Spanish Model} (Percent)

\begin{tabular}{lrrrr}
\hline & $\begin{array}{c}\text { data } \\
\text { direction of exports }\end{array}$ & $\begin{array}{c}\text { model } \\
\text { policy only }\end{array}$ & $\begin{array}{c}\text { model } \\
\text { shocks only }\end{array}$ & $\begin{array}{c}\text { model } \\
\text { policy \& shocks }\end{array}$ \\
\hline Spain to rest of European Community & -6.7 & -3.2 & -4.9 & -7.8 \\
Spain to rest of world & -33.2 & -3.6 & -6.1 & -9.3 \\
rest of European Community to Spain & 14.7 & 4.4 & -3.9 & 0.6 \\
rest of world to Spain & -34.1 & -1.8 & -16.8 & -17.7 \\
& & & \\
weighted correlation with data & & 0.69 & 0.77 & 0.90 \\
variance decomposition of change & & 0.02 & 0.17 & 0.24 \\
& & -12.46 & 2.06 & 5.68 \\
regression coefficient $\boldsymbol{a}$ & & 5.33 & 2.21 & 2.37 \\
regression coefficient $\boldsymbol{b}$ & & &
\end{tabular}




\section{Table 5}

\section{Changes in Trade Flows Relative to GDP in Brown-Deardorff-Stern Model (Percent)}

\begin{tabular}{lrr}
\hline \multicolumn{1}{c}{ data } & model \\
variable & $\mathbf{1 9 8 8}-\mathbf{1 9 9 9}$ & \\
\hline Canadian exports & 52.9 & 4.3 \\
Canadian imports & 57.7 & 4.2 \\
Mexican exports & 140.6 & 50.8 \\
Mexican imports & 50.5 & 34.0 \\
U.S. exports & 19.1 & 2.9 \\
U.S. imports & 29.9 & 2.3 \\
& & \\
weighted correlation with data & & 0.64 \\
variance decomposition of change & & 0.08 \\
& & \\
regression coefficient $\boldsymbol{a}$ & & 23.20 \\
regression coefficient $\boldsymbol{b}$ & & 2.43 \\
\hline
\end{tabular}


Table 6

\section{Changes in Canadian Exports Relative to Canadian GDP in the Brown-Deardorff-Stern Model (Percent)}

\begin{tabular}{|c|c|c|c|c|}
\hline \multirow[b]{2}{*}{ sector } & \multicolumn{2}{|c|}{ exports to Mexico } & \multicolumn{2}{|c|}{ exports to United States } \\
\hline & 1988-1999 & model & 1988-1999 & model \\
\hline agriculture & 122.5 & 3.1 & 106.1 & 3.4 \\
\hline mining and quarrying & -34.0 & -0.3 & 75.8 & 0.4 \\
\hline food & 89.3 & 2.2 & 91.7 & 8.9 \\
\hline textiles & 268.2 & -0.9 & 97.8 & 15.3 \\
\hline clothing & 1544.3 & 1.3 & 237.1 & 45.3 \\
\hline leather products & 443.0 & 1.4 & -14.4 & 11.3 \\
\hline footwear & 517.0 & 3.7 & 32.8 & 28.3 \\
\hline wood products & 232.6 & 4.7 & 36.5 & 0.1 \\
\hline furniture and fixtures & 3801.7 & 2.7 & 282.6 & 12.5 \\
\hline paper products & 240.7 & -4.3 & 113.7 & -1.8 \\
\hline printing and publishing & 6187.4 & -2.0 & 37.2 & -1.6 \\
\hline chemicals & 37.1 & -7.8 & 109.4 & -3.1 \\
\hline petroleum and products & 678.1 & -8.5 & -42.5 & 0.5 \\
\hline rubber products & 647.4 & -1.0 & 113.4 & 9.5 \\
\hline nonmetal mineral products & 333.5 & -1.8 & 20.5 & 1.2 \\
\hline glass products & 264.4 & -2.2 & 74.5 & 30.4 \\
\hline iron and steel & 195.2 & -15.0 & 92.1 & 12.9 \\
\hline nonferrous metals & 38.4 & -64.7 & 34.7 & 18.5 \\
\hline metal products & 767.0 & -10.0 & 102.2 & 15.2 \\
\hline nonelectrical machinery & 376.8 & -8.9 & 28.9 & 3.3 \\
\hline electrical machinery & 633.9 & -26.2 & 88.6 & 14.5 \\
\hline transportation equipment & 305.8 & -4.4 & 30.7 & 10.7 \\
\hline miscellaneous manufactures & 1404.5 & -12.1 & 100.0 & -2.1 \\
\hline \multirow{2}{*}{\multicolumn{2}{|c|}{$\begin{array}{l}\text { weighted correlation with data } \\
\text { variance decomposition of change }\end{array}$}} & -0.91 & & -0.43 \\
\hline & & 0.003 & & 0.02 \\
\hline regression coefficient $a$ & & 249.24 & & 79.20 \\
\hline regression coefficient $\boldsymbol{b}$ & & -15.48 & & -2.80 \\
\hline
\end{tabular}




\section{Table 7}

\section{Changes in Mexican Exports Relative to GDP in the Brown-Deardorff-Stern Model \\ (Percent)}

\begin{tabular}{lrrrr}
\hline & \multicolumn{2}{c}{ exports to Canada } & \multicolumn{2}{c}{ exports to United States } \\
sector & $\mathbf{1 9 8 8}-\mathbf{1 9 9 9}$ & model & $\mathbf{1 9 8 8}-\mathbf{1 9 9 9}$ & model \\
\hline agriculture & -20.5 & -4.1 & -15.0 & 2.5 \\
mining and quarrying & -35.5 & 27.3 & -22.9 & 26.9 \\
food & 70.4 & 10.8 & 9.4 & 7.5 \\
textiles & 939.7 & 21.6 & 832.3 & 11.8 \\
clothing & 1847.0 & 19.2 & 829.6 & 18.6 \\
leather products & 1470.3 & 36.2 & 618.3 & 11.7 \\
footwear & 153.0 & 38.6 & 111.1 & 4.6 \\
wood products & 4387.6 & 15.0 & 145.6 & -2.7 \\
furniture and fixtures & 4933.2 & 36.2 & 181.2 & 7.6 \\
paper products & 23.9 & 32.9 & 70.3 & 13.9 \\
printing and publishing & 476.3 & 15.0 & 122.1 & 3.9 \\
chemicals & 204.6 & 36.0 & 70.4 & 17.0 \\
petroleum and products & -10.6 & 32.9 & 66.4 & 34.1 \\
rubber products & 2366.2 & -6.7 & 783.8 & -5.3 \\
nonmetal mineral products & 1396.1 & 5.7 & 222.3 & 3.7 \\
glass products & 676.8 & 13.3 & 469.8 & 32.3 \\
iron and steel & 32.5 & 19.4 & 40.9 & 30.8 \\
nonferrous metals & -35.4 & 138.1 & 111.2 & 156.5 \\
metal products & 610.4 & 41.9 & 477.2 & 26.8 \\
nonelectrical machinery & 570.6 & 17.3 & 123.6 & 18.5 \\
electrical machinery & 1349.2 & 137.3 & 744.9 & 178.0 \\
transportation equipment & 2303.4 & 3.3 & 349.0 & 6.2 \\
miscellaneous manufactures & 379.4 & 61.1 & 181.5 & 43.2 \\
weighted correlation with data & & & & \\
variance decomposition of change & & 0.19 & & 0.71 \\
regression coefficient $\boldsymbol{a}$ & & 0.01 & & 0.04 \\
regression coefficient $\boldsymbol{b}$ & & & & 38.13 \\
\hline & & 120.32 & & 3.87 \\
\hline
\end{tabular}


Table 8

\section{Changes in U.S. Exports Relative to U.S. GDP in the Brown-Deardorff-Stern Model \\ (Percent)}

\begin{tabular}{|c|c|c|c|c|}
\hline \multirow[b]{2}{*}{ sector } & \multicolumn{2}{|c|}{ exports to Canada } & \multicolumn{2}{|c|}{ exports to Mexico } \\
\hline & 1988-1999 & model & 1988-1999 & model \\
\hline agriculture & -24.1 & 5.1 & 6.5 & 7.9 \\
\hline mining and quarrying & -23.6 & 1.0 & -19.8 & 0.5 \\
\hline food & 62.4 & 12.7 & 37.7 & 13.0 \\
\hline textiles & 177.2 & 44.0 & 850.5 & 18.6 \\
\hline clothing & 145.5 & 56.7 & 543.0 & 50.3 \\
\hline leather products & 29.9 & 7.9 & 87.7 & 15.5 \\
\hline footwear & 48.8 & 45.7 & 33.1 & 35.4 \\
\hline wood products & 76.4 & 6.7 & 25.7 & 7.0 \\
\hline furniture and fixtures & 83.8 & 35.6 & 224.1 & 18.6 \\
\hline paper products & -20.5 & 18.9 & -41.9 & -3.9 \\
\hline printing and publishing & 50.8 & 3.9 & 507.9 & -1.1 \\
\hline chemicals & 49.8 & 21.8 & 61.5 & -8.4 \\
\hline petroleum and products & -6.9 & 0.8 & -41.1 & -7.4 \\
\hline rubber products & 95.6 & 19.1 & 165.6 & 12.8 \\
\hline nonmetal mineral products & 56.5 & 11.9 & 55.9 & 0.8 \\
\hline glass products & 50.5 & 4.4 & 112.9 & 42.3 \\
\hline iron and steel & 0.6 & 11.6 & 144.5 & -2.8 \\
\hline nonferrous metals & -20.7 & -6.7 & -28.7 & -55.1 \\
\hline metal products & 66.7 & 18.2 & 301.4 & 5.4 \\
\hline nonelectrical machinery & 36.2 & 9.9 & 350.8 & -2.9 \\
\hline electrical machinery & 154.4 & 14.9 & 167.8 & -10.9 \\
\hline transportation equipment & 36.5 & -4.6 & 290.3 & 9.9 \\
\hline miscellaneous manufactures & 117.3 & 11.5 & 362.3 & -9.4 \\
\hline \multirow{2}{*}{\multicolumn{2}{|c|}{$\begin{array}{l}\text { weighted correlation with data } \\
\text { variance decomposition of change }\end{array}$}} & -0.01 & & 0.50 \\
\hline & & 0.14 & & 0.02 \\
\hline \multirow{2}{*}{\multicolumn{2}{|c|}{$\begin{array}{l}\text { regression coefficient } \boldsymbol{a} \\
\text { regression coefficient } \boldsymbol{b}\end{array}$}} & 37.27 & & 190.89 \\
\hline & & -0.02 & & 3.42 \\
\hline
\end{tabular}


Table 9

Changes in Canadian Trade Volumes Relative to Canadian GDP in Cox-Harris Model

(Percent)

\begin{tabular}{lrr}
\hline \multicolumn{1}{c}{$\begin{array}{c}\text { data } \\
\text { variable }\end{array}$} & model \\
\hline total trade & 57.2 & 10.0 \\
trade with Mexico & 280.0 & 52.2 \\
trade with United States & 76.2 & 20.0 \\
& & \\
weighted correlation with data & 0.99 \\
variance decomposition of change & 0.52 \\
& \\
regression coefficient $\boldsymbol{a}$ & 38.40 \\
regression coefficient $\boldsymbol{b}$ & 1.93 \\
\hline
\end{tabular}


Table 10

\section{Changes in Canadian Trade Relative to Canadian GDP in the Cox-Harris Model \\ (Percent)}

\begin{tabular}{lrrrr}
\hline & \multicolumn{2}{c}{ total exports } & \multicolumn{2}{c}{ total imports } \\
sector & $\mathbf{1 9 8 8}-\mathbf{2 0 0 0}$ & model & $\mathbf{1 9 8 8}-\mathbf{2 0 0 0}$ & model \\
\hline agriculture & -13.7 & -4.1 & 4.6 & 7.2 \\
forestry & 215.5 & -11.5 & -21.5 & 7.1 \\
fishing & 81.5 & -5.4 & 107.3 & 9.5 \\
mining & 21.7 & -7.0 & 32.1 & 4.0 \\
food, beverages, and tobacco & 50.9 & 18.6 & 60.0 & 3.8 \\
rubber and plastics & 194.4 & 24.5 & 87.7 & 13.8 \\
textiles and leather & 201.1 & 108.8 & 24.6 & 18.2 \\
wood and paper & 31.9 & 7.3 & 97.3 & 7.2 \\
steel and metal products & 30.2 & 19.5 & 52.2 & 10.0 \\
transportation equipment & 66.3 & 3.5 & 29.7 & 3.0 \\
machinery and appliances & 112.9 & 57.1 & 65.0 & 13.3 \\
nonmetallic minerals & 102.7 & 31.8 & 3.6 & 7.3 \\
refineries & 20.3 & -2.7 & 5.1 & 1.5 \\
chemicals and misc. manufactures & 53.3 & 28.1 & 92.5 & 10.4 \\
& & & & \\
weighted correlation with data & & 0.49 & & 0.85 \\
variance decomposition of change & & 0.32 & & 0.08 \\
regression coefficient $\boldsymbol{a}$ & & & & \\
regression coefficient $\boldsymbol{b}$ & & 41.85 & & \\
& & 0.81 & & \\
\hline
\end{tabular}




\section{Table 11}

\section{Changes in Mexican Trade Relative to Mexican GDP in the Sobarzo Model (Percent)}

\begin{tabular}{|c|c|c|c|c|}
\hline \multirow[b]{2}{*}{ sector } & \multicolumn{2}{|c|}{ exports to North America } & \multicolumn{2}{|c|}{ imports from North America } \\
\hline & 1988-2000 & model & 1988-2000 & model \\
\hline agriculture & -15.3 & -11.1 & -28.2 & 3.4 \\
\hline mining & -23.2 & -17.0 & -50.7 & 13.2 \\
\hline petroleum & -37.6 & -19.5 & 65.9 & -6.8 \\
\hline food & 5.2 & -6.9 & 11.8 & -5.0 \\
\hline beverages & 42.0 & 5.2 & 216.0 & -1.8 \\
\hline tobacco & -42.3 & 2.8 & 3957.1 & -11.6 \\
\hline textiles & 534.1 & 1.9 & 833.2 & -1.2 \\
\hline wearing apparel & 2097.3 & 30.0 & 832.9 & 4.5 \\
\hline leather & 264.3 & 12.4 & 621.0 & -0.4 \\
\hline wood & 415.1 & -8.5 & 168.9 & 11.7 \\
\hline paper & 12.8 & -7.9 & 68.1 & -4.7 \\
\hline chemicals & 41.9 & -4.4 & 71.8 & -2.7 \\
\hline rubber & 479.0 & 12.8 & 792.0 & -0.1 \\
\hline nonmetallic mineral products & 37.5 & -6.2 & 226.5 & 10.9 \\
\hline iron and steel & 35.9 & -4.9 & 40.3 & 17.7 \\
\hline nonferrous metals & -40.3 & -9.8 & 101.2 & 9.8 \\
\hline metal products & 469.5 & -4.4 & 478.7 & 9.5 \\
\hline nonelectrical machinery & 521.7 & -7.4 & 129.0 & 20.7 \\
\hline electrical machinery & 3189.1 & 1.0 & 749.1 & 9.6 \\
\hline transportation equipment & 224.5 & -5.0 & 368.0 & 11.2 \\
\hline other manufactures & 975.1 & -4.5 & 183.6 & 4.2 \\
\hline \multirow{2}{*}{\multicolumn{2}{|c|}{$\begin{array}{l}\text { weighted correlation with data } \\
\text { variance decomposition of change }\end{array}$}} & 0.61 & & 0.23 \\
\hline & & 0.0004 & & 0.002 \\
\hline regression coefficient $a$ & & 495.08 & & 174.52 \\
\hline regression coefficient $\boldsymbol{b}$ & & 30.77 & & 5.35 \\
\hline
\end{tabular}


Table A1

Concordance from SITC to ISIC Non-Manufactures

\begin{tabular}{l|l|l|l|l|l}
\hline $\begin{array}{l}\text { ISIC } \\
\text { Code }\end{array}$ & \multirow{2}{*}{ 3 Digit SITC } & \multicolumn{2}{|c|}{ 4 Digit SITC } & \multicolumn{2}{c}{ 5 Digit SITC } \\
\hline & \multicolumn{1}{|c|}{ Add } & \multicolumn{1}{|c|}{ Add } & \multicolumn{1}{c}{ Subtract } & \multicolumn{1}{c}{ Add } & \multicolumn{1}{c}{ Subtract } \\
\hline 11 & $001,041,043$, & 0251,0421, & 0546, & 07111,08111, & 05771,05774, \\
& $044,045,054$, & 0616,0721, & 0572, & 08112,09808, & 05775,05799, \\
& $057,075,212$, & 0742,1211, & 0576, & 21199,26901, & 07528,26512, \\
& $222,223,264$, & $0.5 \times 2681,2683$, & 2223, & 29115,29191, & 26513,26599, \\
& $265,271,292$ & 2685 & 2232,2239 & 29197 & 29291 \\
\hline 12 & $232,244,245$, & & & 23322,24601 & 24402,24502 \\
& 247 & & & & \\
\hline 130 & & $0.7 \times 0036,0341$ & & 32313 & \\
\hline 210 & 322 & & & & 28731 \\
\hline 220 & 333,341 & & 2814 & & 28902 \\
\hline 230 & $281,286,287$, & & & & 28732, \\
& 289 & & & & 27861 \\
\hline 290 & $273,274,277$, & & & & \\
\hline
\end{tabular}


Table A2

\section{Concordance Between ISIC and Cox-Harris Aggregates}

\begin{tabular}{ll}
\hline Cox-Harris Aggregate & ISIC Code \\
\hline agriculture & 11 \\
forestry & 12 \\
fishing & 13 \\
mining & 2 \\
food, beverages, and tobacco & $311+312+313+314$ \\
rubber and plastics & $355+356$ \\
textiles and leather & $321+323$ \\
wood and paper & $331+332+341$ \\
steel and metal products & $371+372+381$ \\
transportation equipment & 384 \\
machinery and appliances & $382+383$ \\
nonmetallic minerals & $361+369$ \\
refineries & $353+354$ \\
chemicals and misc. manufactures & $351+352+385$ \\
\hline
\end{tabular}


Table A3

\section{Concordance Between ISIC and Sobarzo Aggregates}

\begin{tabular}{lc}
\hline Sobarzo Aggregate & ISIC Code \\
\hline agriculture & 1 \\
mining & 2 \\
petroleum & $354+353$ \\
food & $311+312$ \\
beverages & 313 \\
tobacco & 314 \\
textiles & 321 \\
wearing apparel & 322 \\
leather & 323 \\
wood & $331+332$ \\
paper & 341 \\
chemicals & $351+352$ \\
rubber & $355+356$ \\
nonmetallic mineral products & $361+369$ \\
iron and steel & 371 \\
nonferrous metals & 372 \\
metal products & 381 \\
nonelectrical machinery & 382 \\
electrical machinery & 383 \\
transportation equipment & 384 \\
other manufactures & 385 \\
\hline
\end{tabular}


Figure 1

Composition of Exports: Canada to Mexico

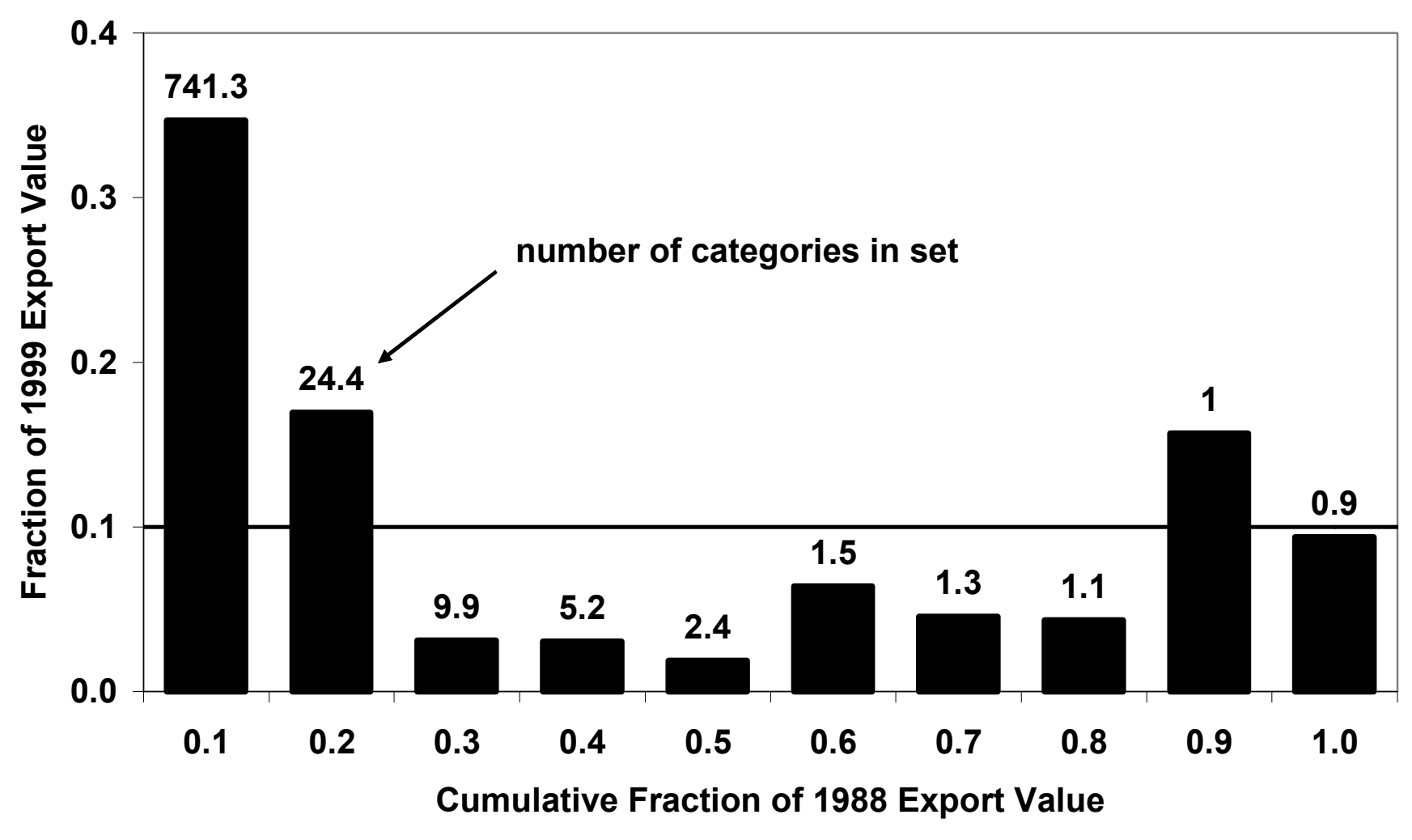


Figure 2

Composition of Exports: Mexico to Canada

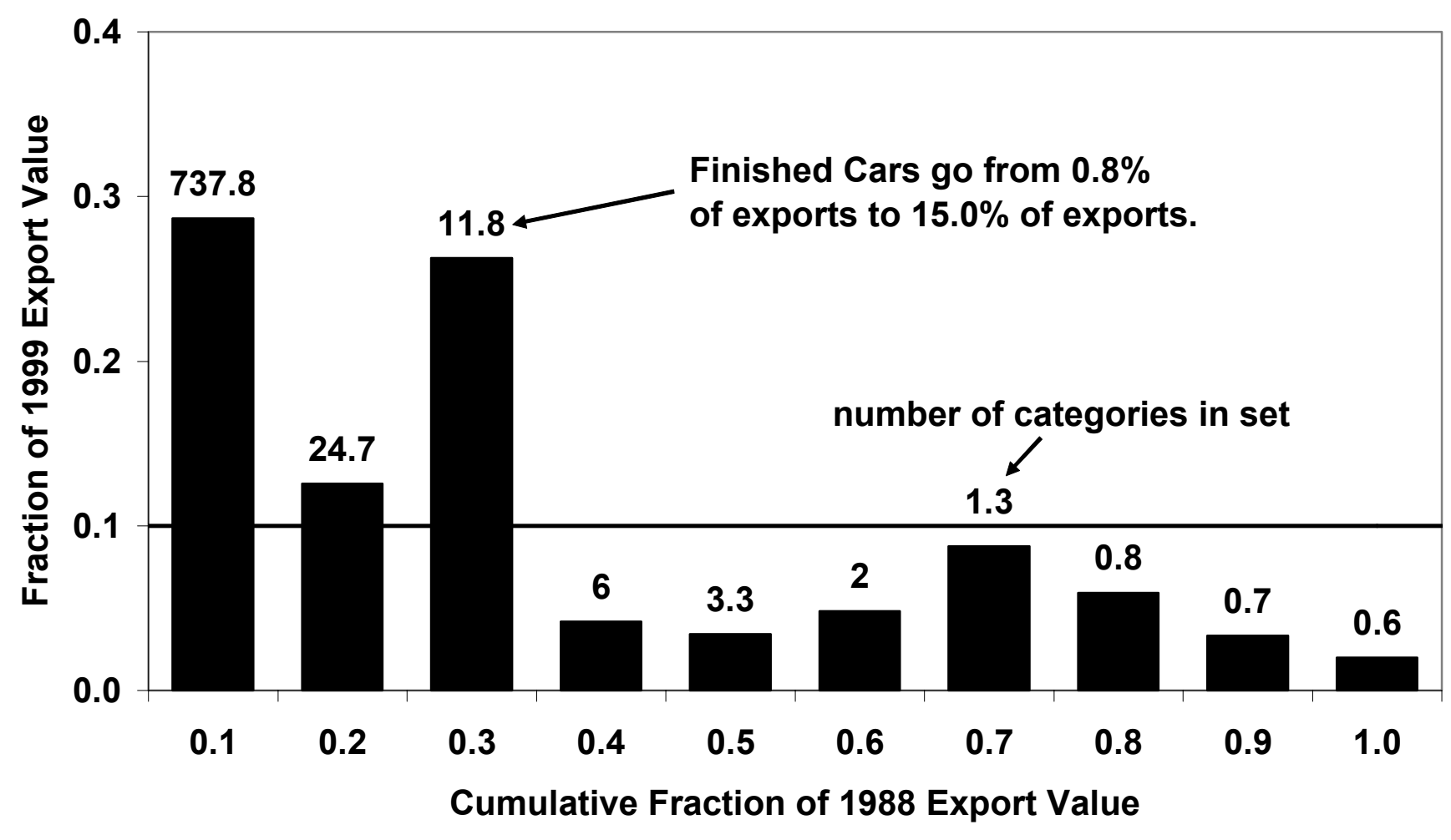


Figure 3

Exports: Canada to Mexico

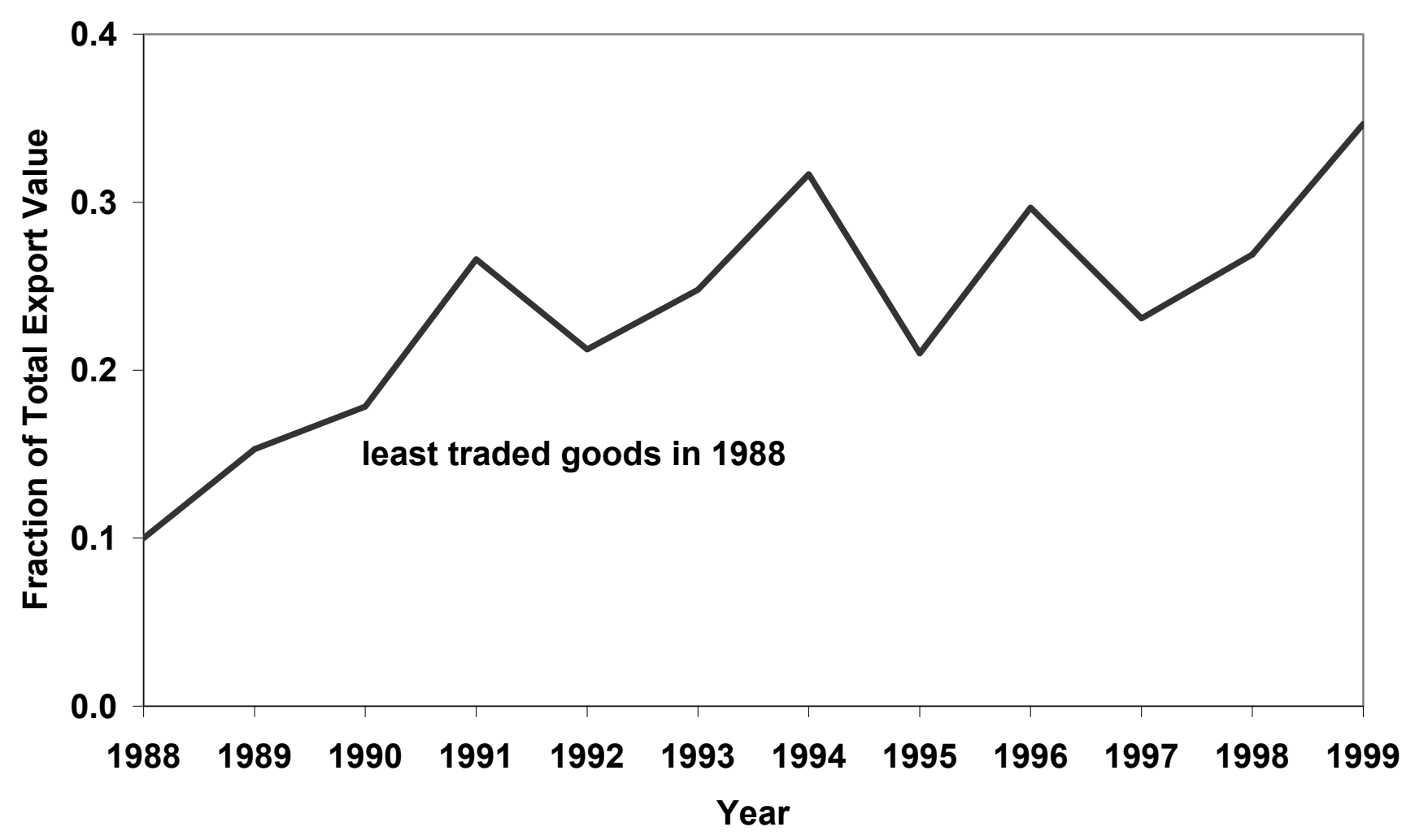


Figure 4

\section{Exports: Mexico to Canada}

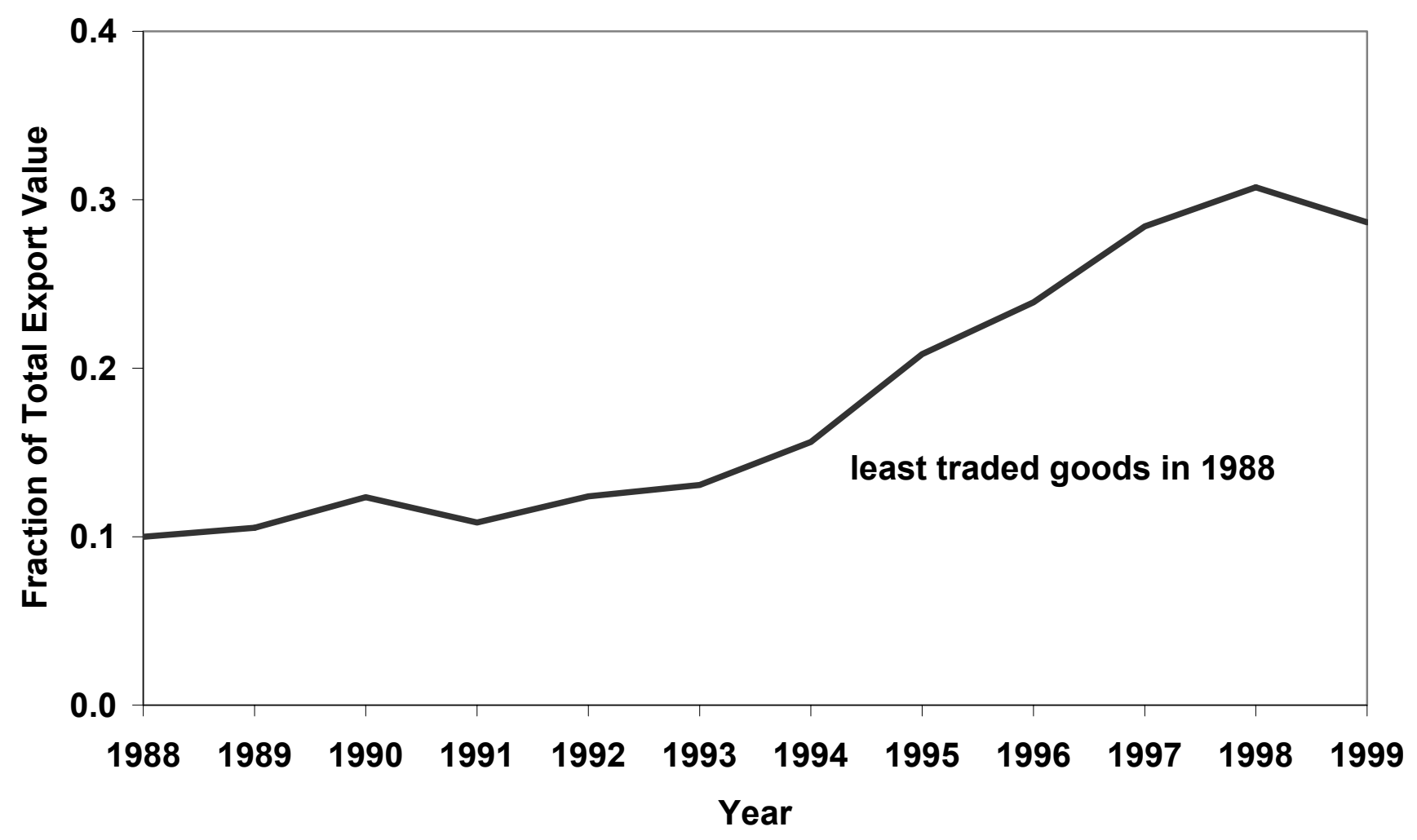


Figure 5

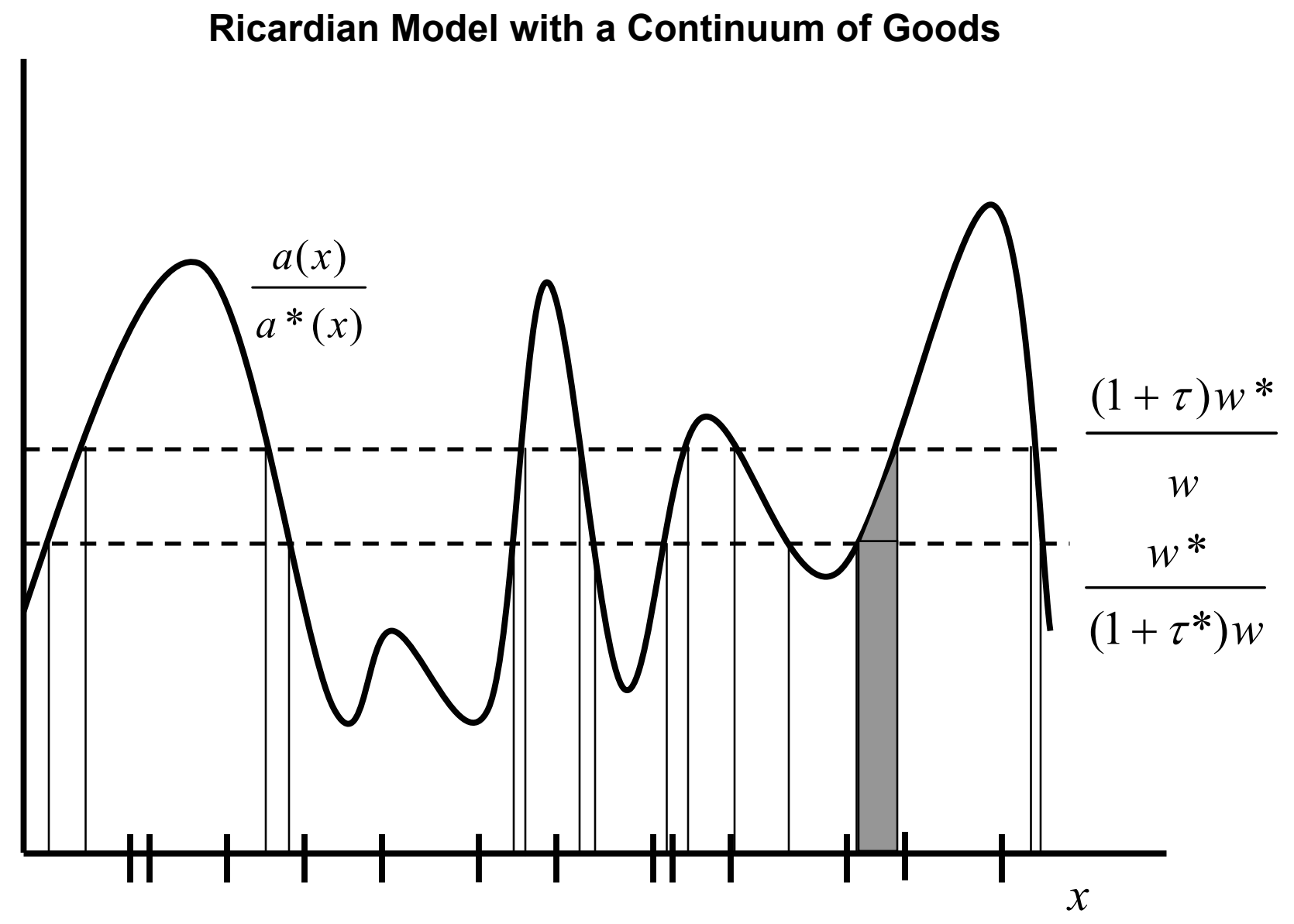


Figure 6

Y/N

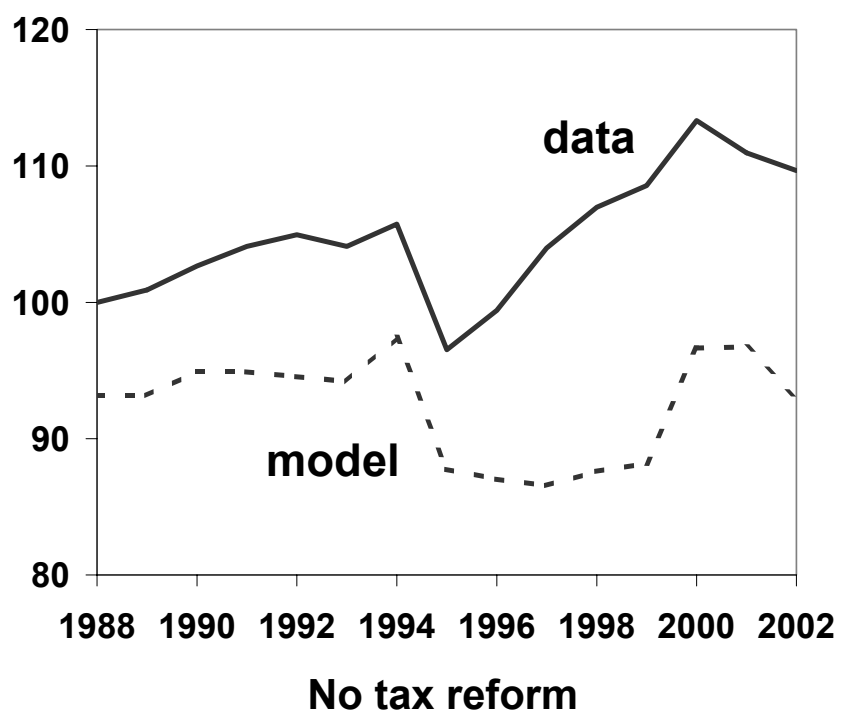

\section{Y/N}

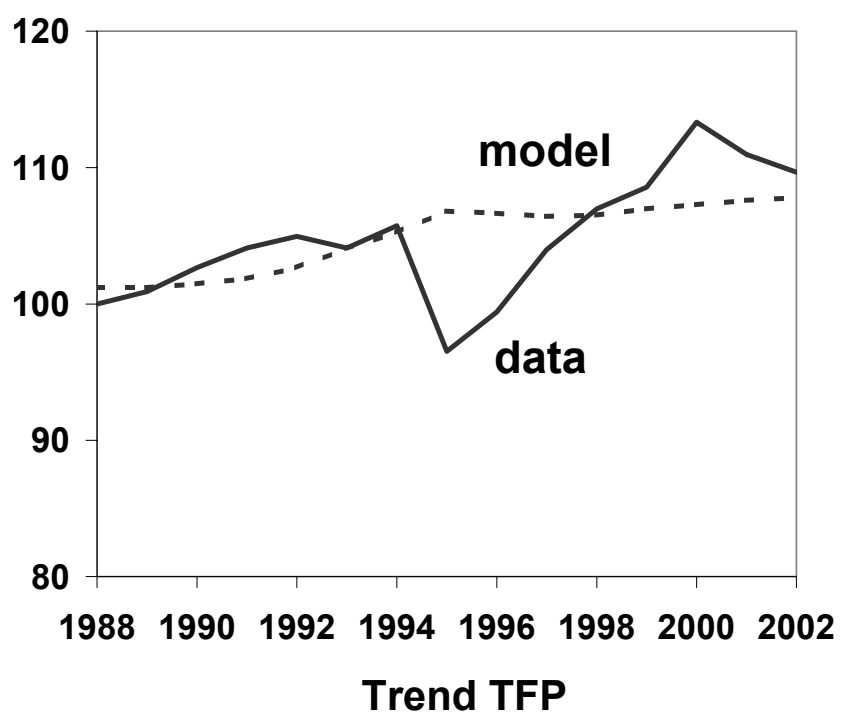

\section{Y/N}

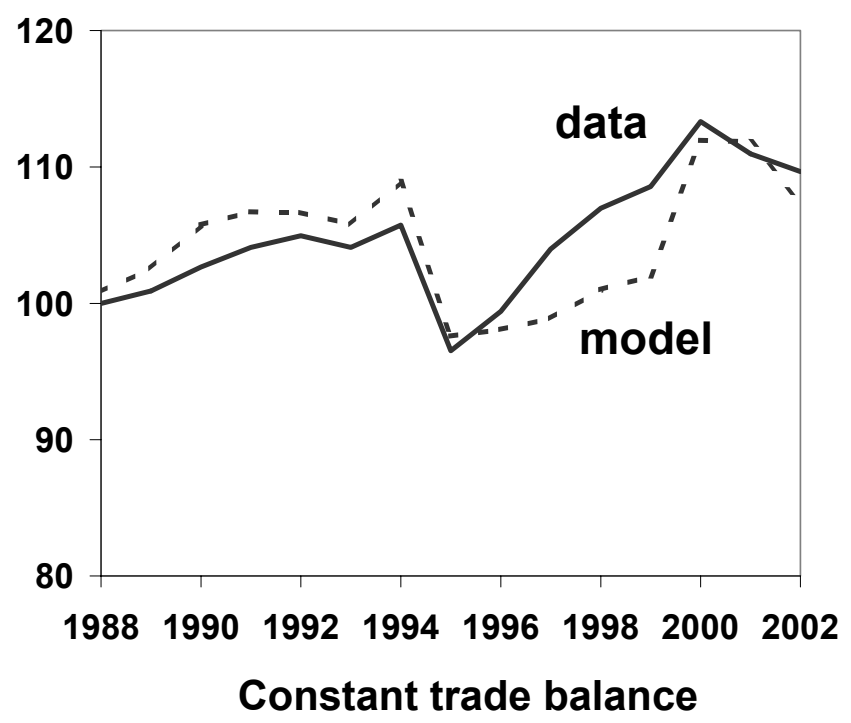

\section{Y/N}

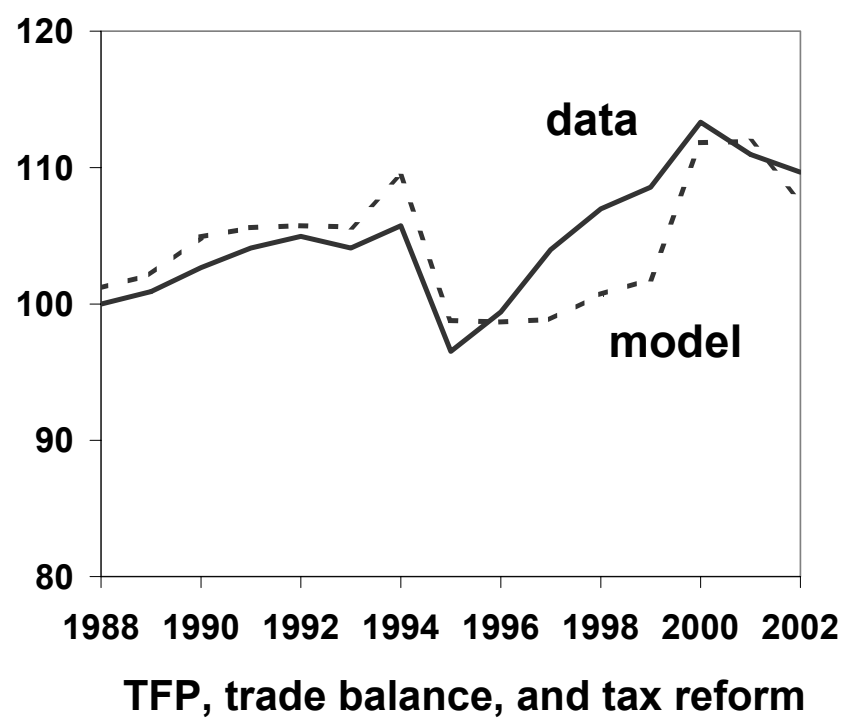




\section{Figure 7}

$\mathrm{K} / \mathrm{Y}$

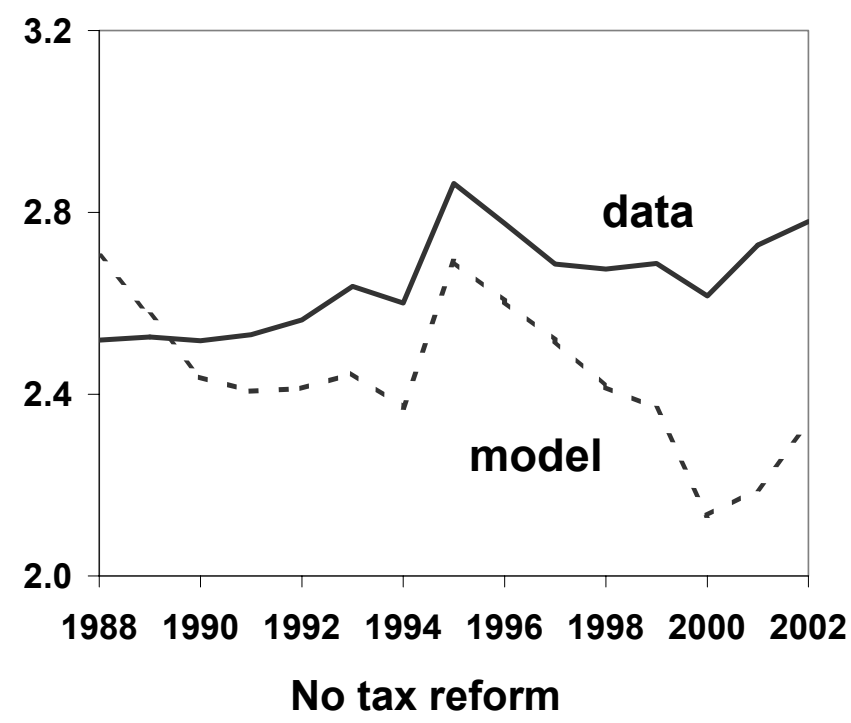

$K / Y$

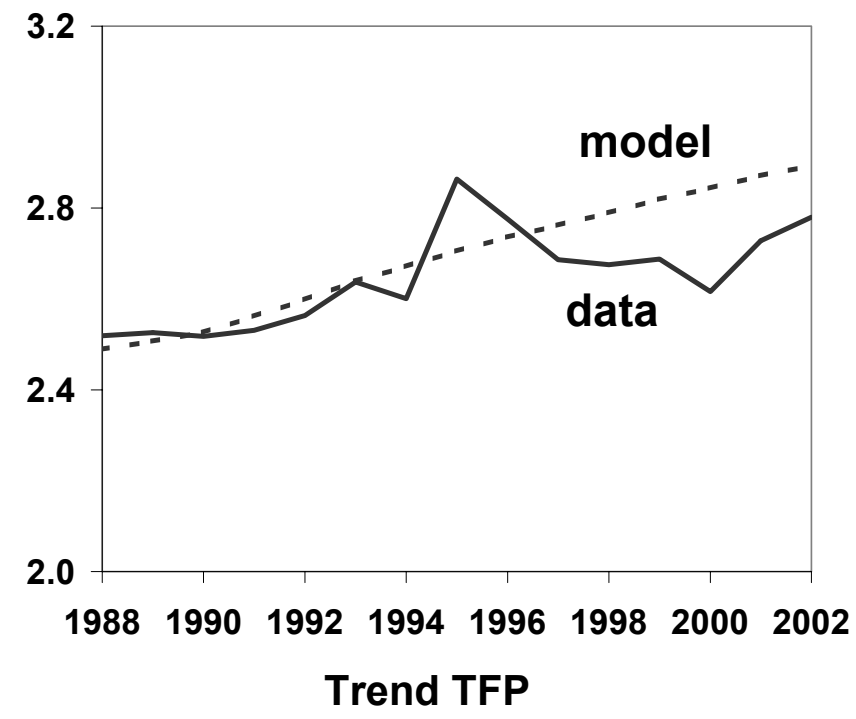

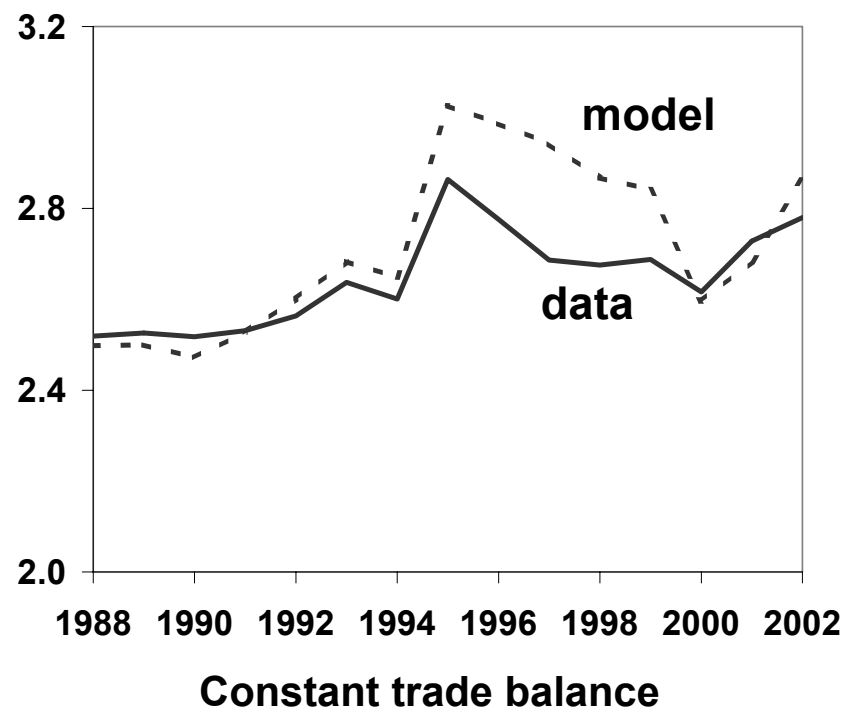

$\mathrm{K} / \mathrm{Y}$

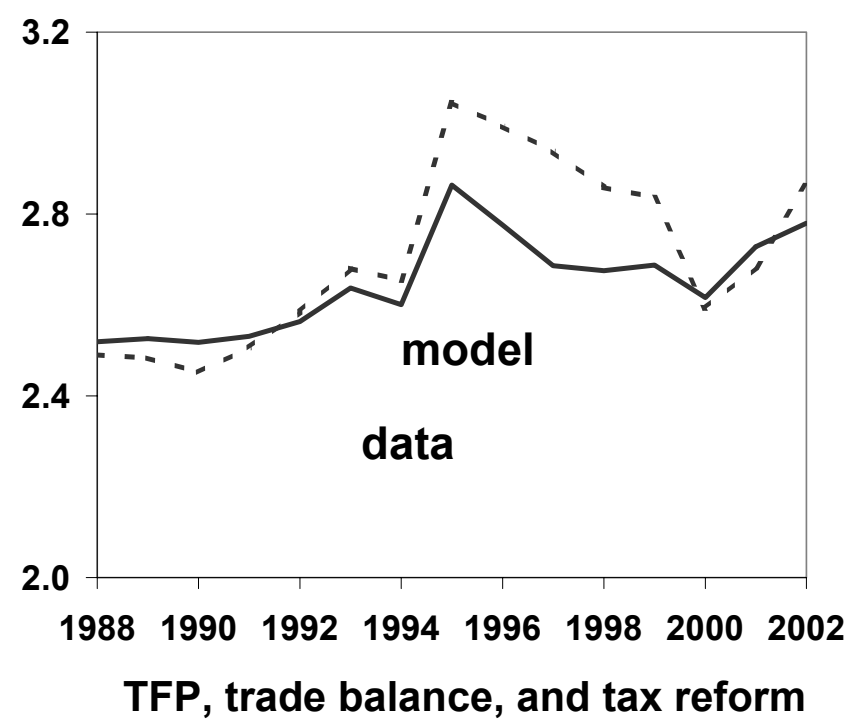




\section{Figure 8}

\section{L/N}

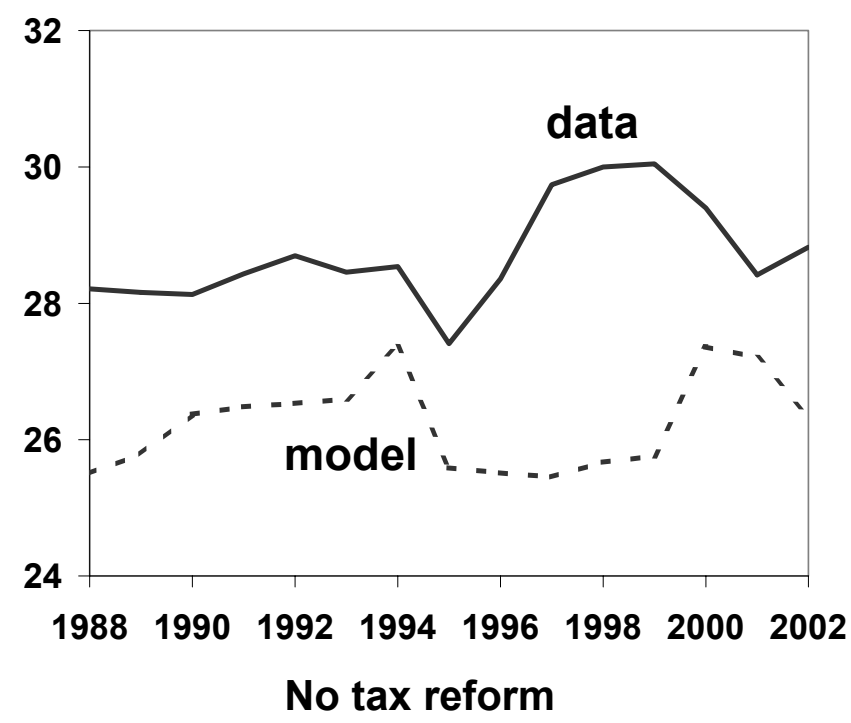

L/N

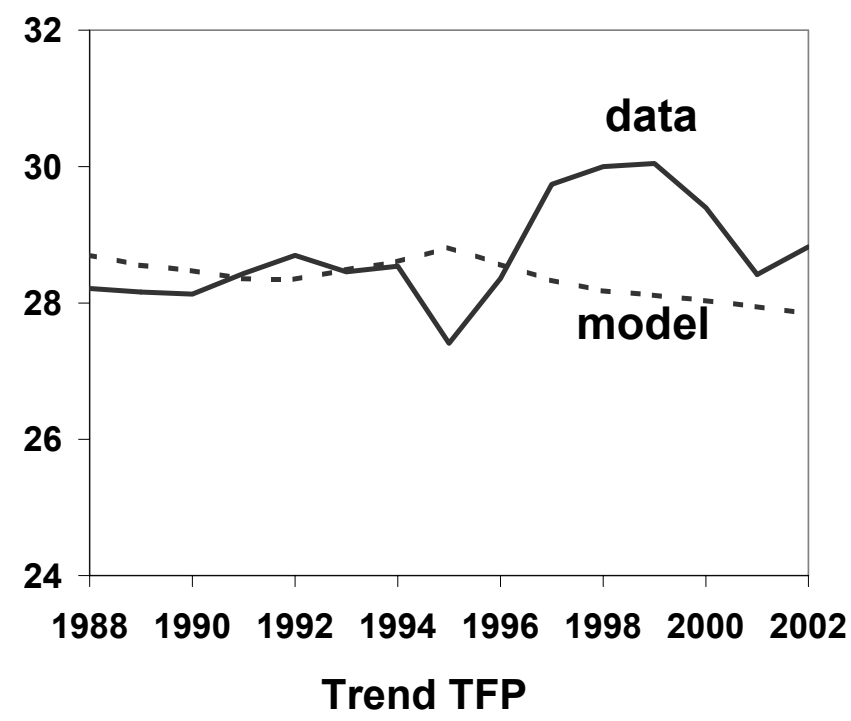

L/N

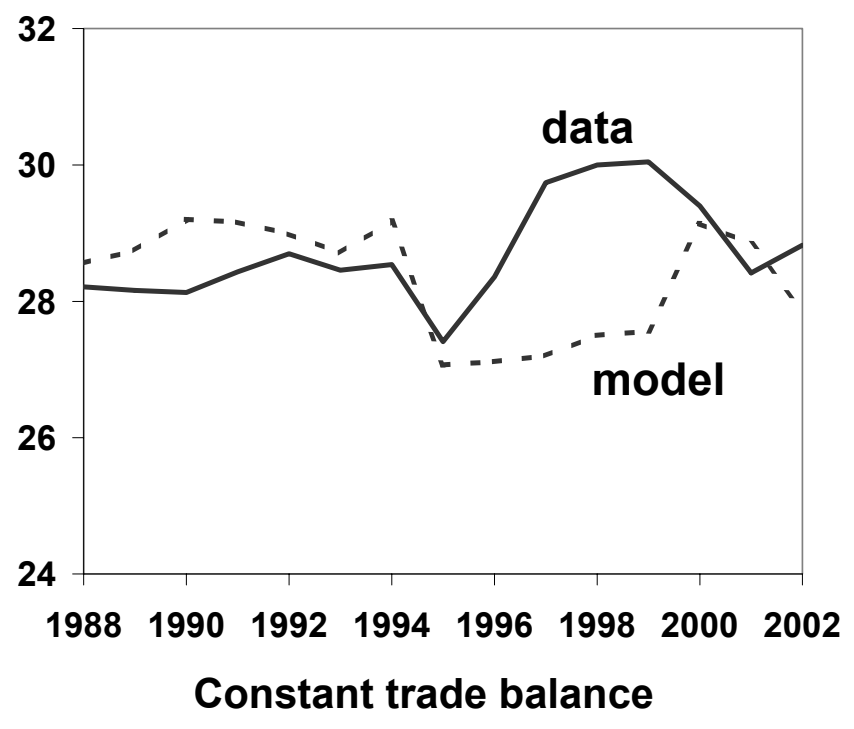

L/N

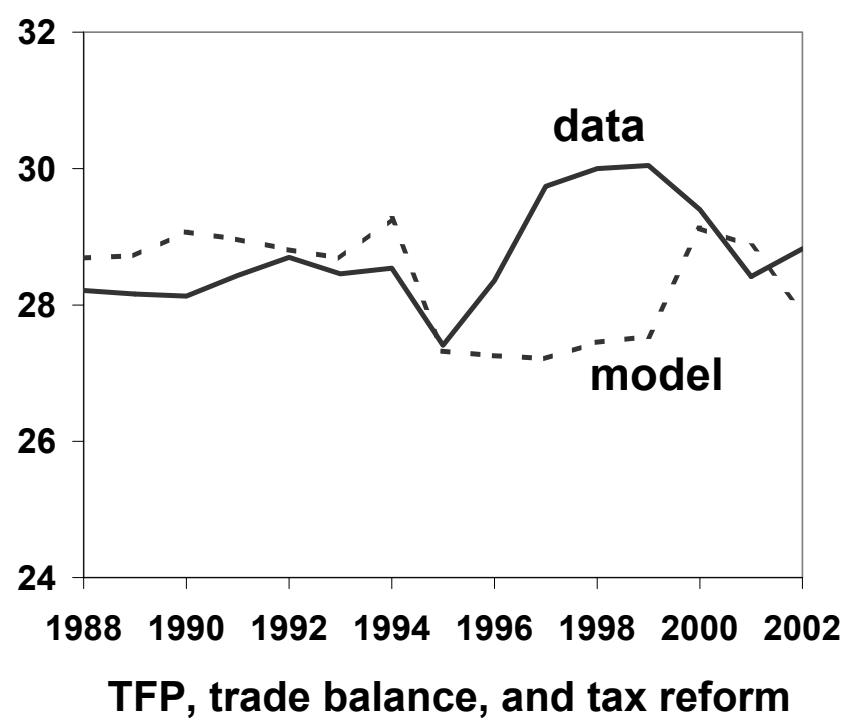




\section{Figure 9}

$\mathrm{I} / \mathrm{Y}$

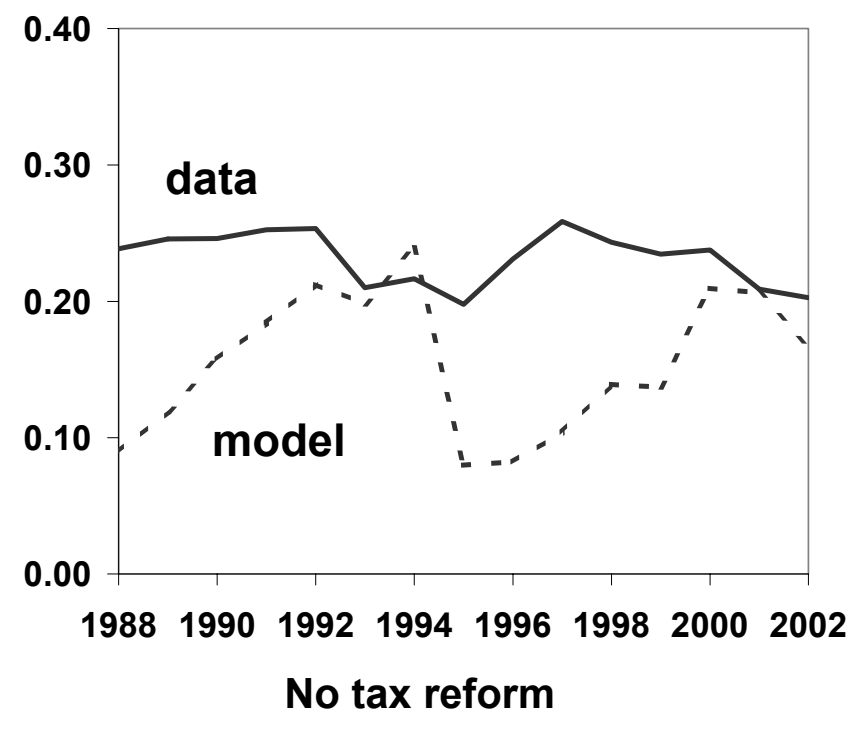

I/Y

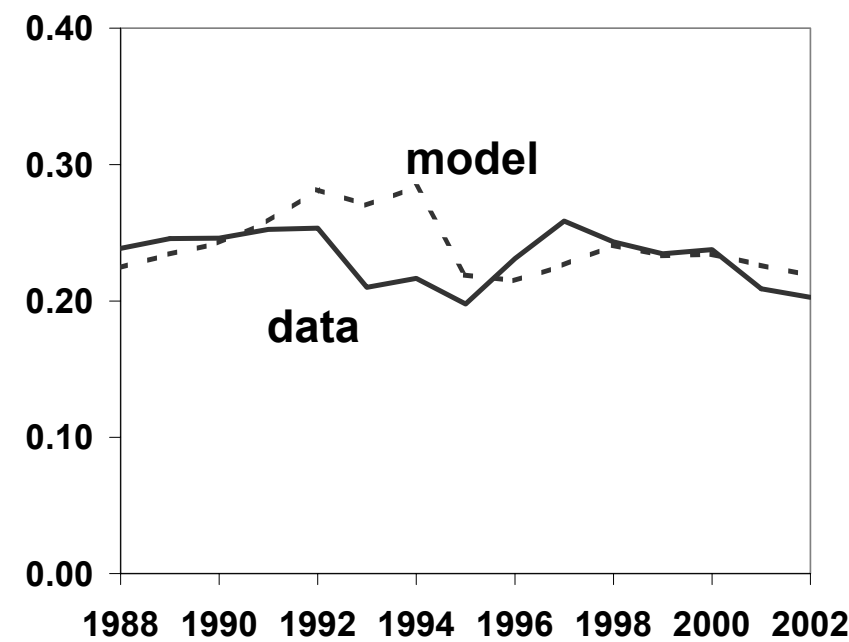

Trend TFP
$\mathrm{I} / \mathrm{Y}$

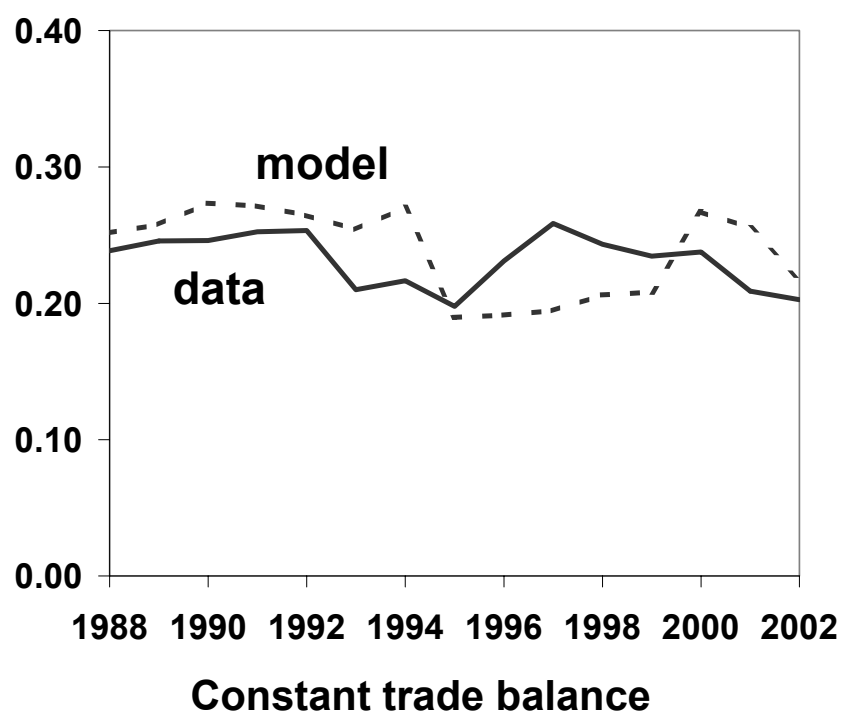

$\mathrm{I} / \mathrm{Y}$

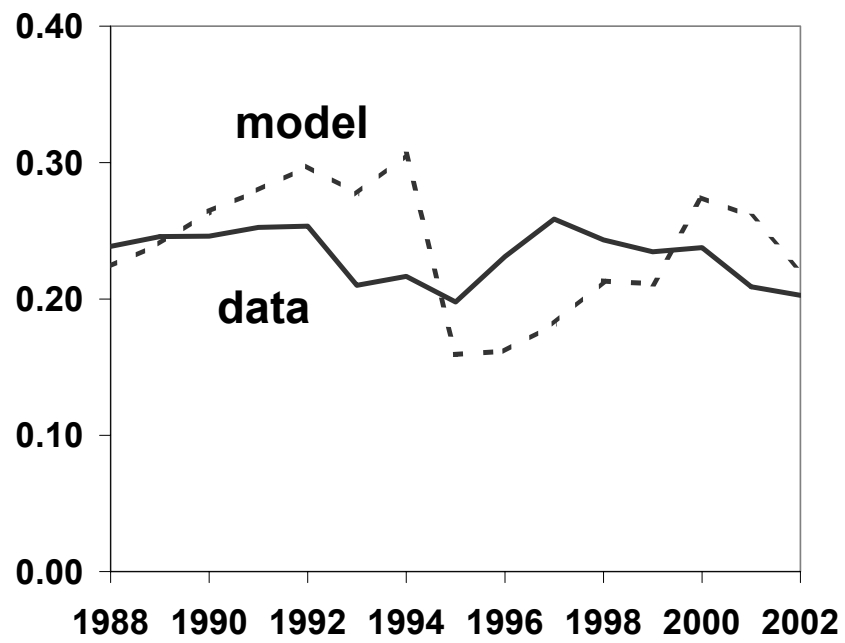

TFP, trade balance, and tax reform 